Supporting Information

\title{
Multifunctional Zn(II) Complexes: Photophysical \\ Properties and Catalytic Transesterification Towards \\ Biodiesel Synthesis
}




\section{Synthesis of ligand 3D}

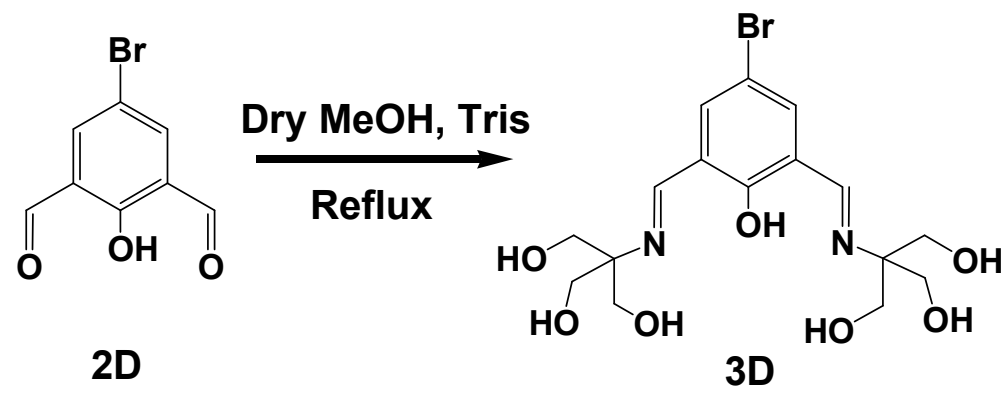

Scheme S1. Synthetic scheme of ligand 3D

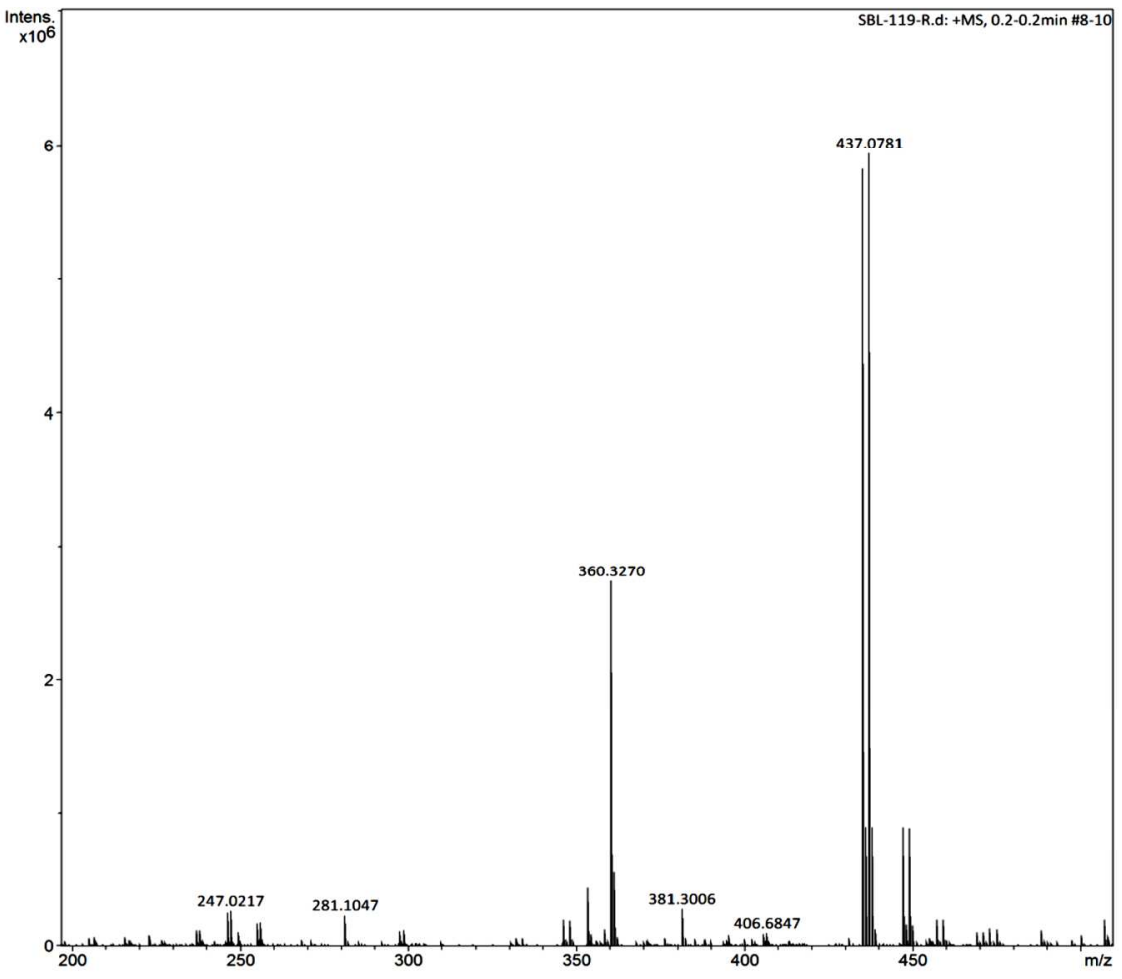

Figure S1. ESI-MS spectrum of 3D. The peak at $\mathrm{m} / \mathrm{z} 437.0781$ corresponds to $[3 \mathbf{D}+\mathrm{H}]^{+}$ 
${ }^{1}$ H NMR spectrum of 3D

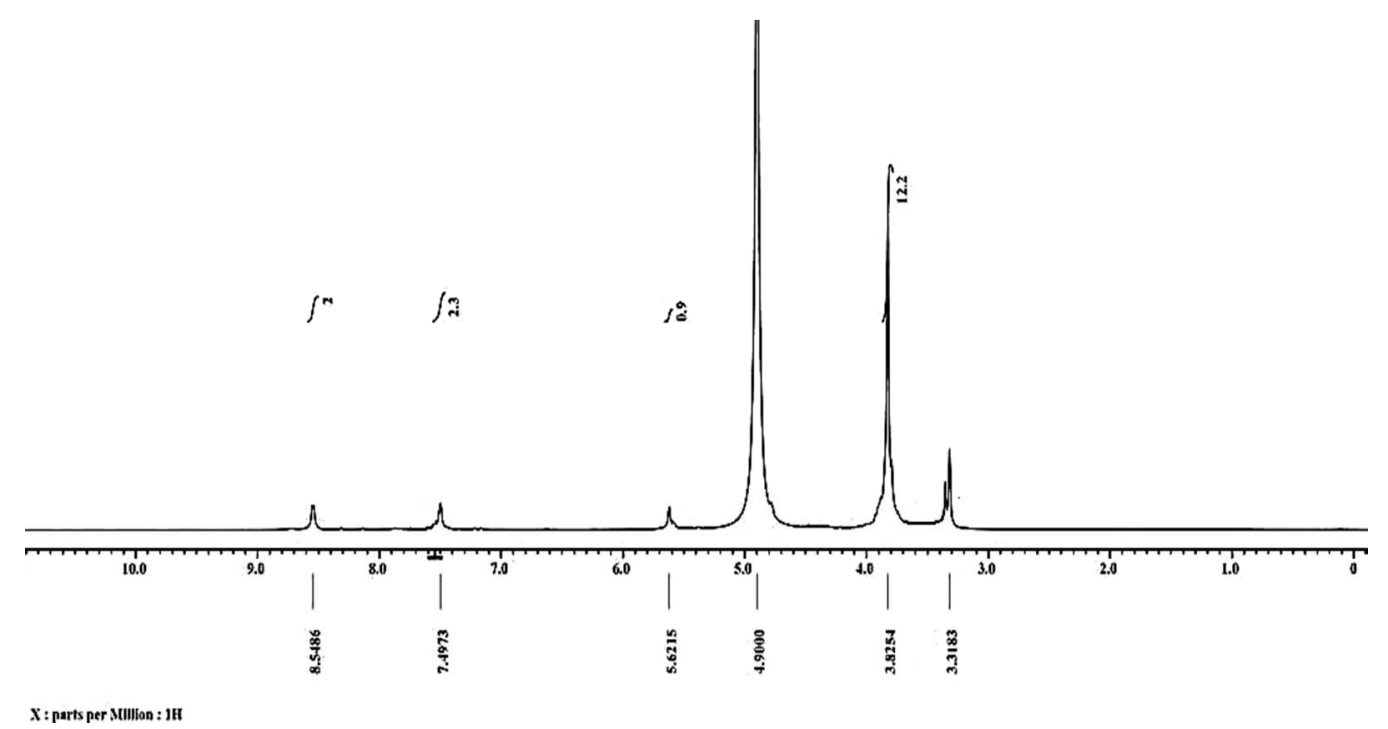

${ }^{13}$ C NMR spectrum of 3D

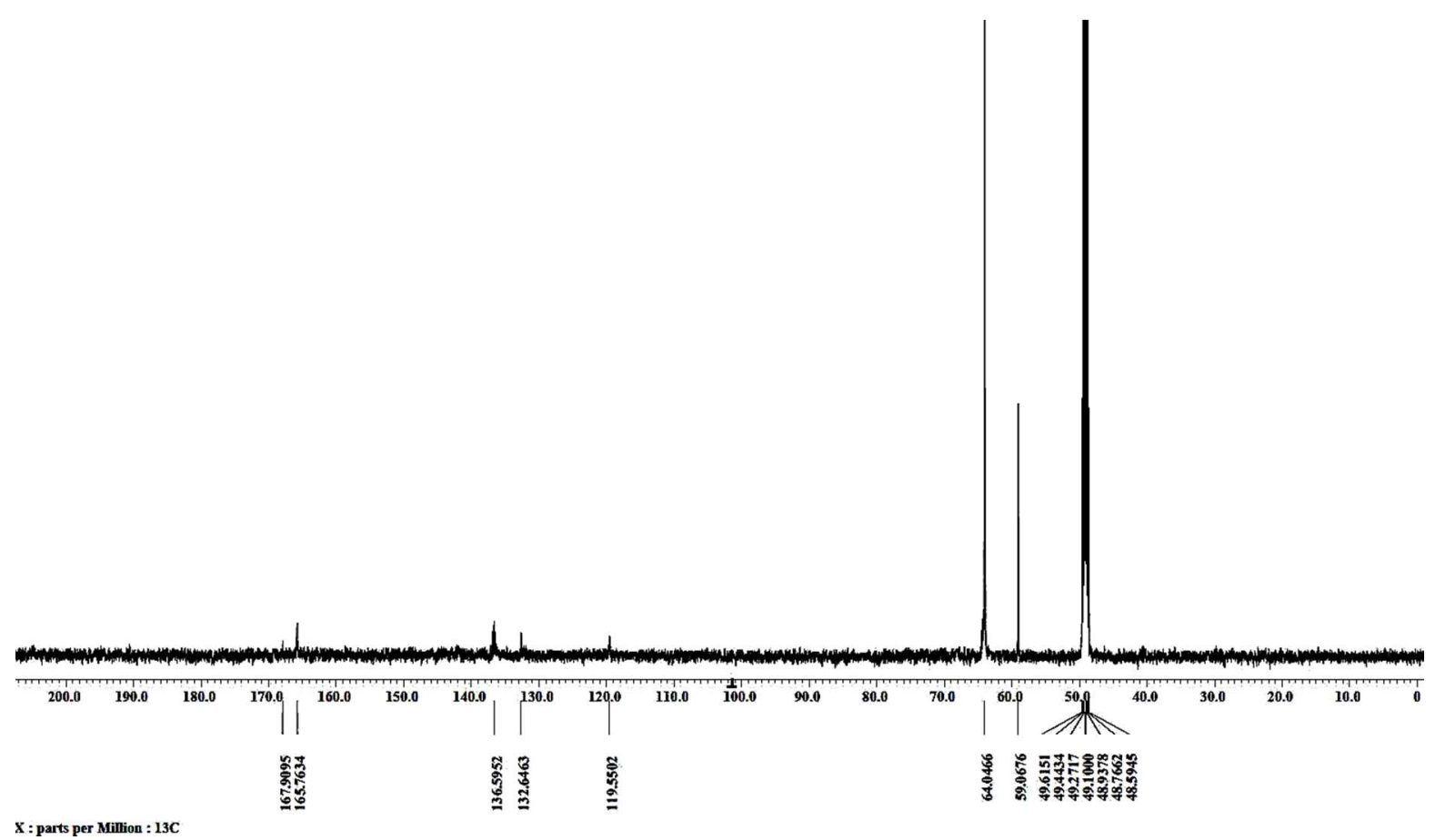


2. Mass spectrum of $4 \mathrm{~A},\left[\mathrm{Zn}_{2}(\mathrm{OMe}-\mathrm{dfp})(\mathrm{OAc})_{2}\right](\mathrm{OAc}) \cdot 2 \mathrm{H}_{2} \mathrm{O}$

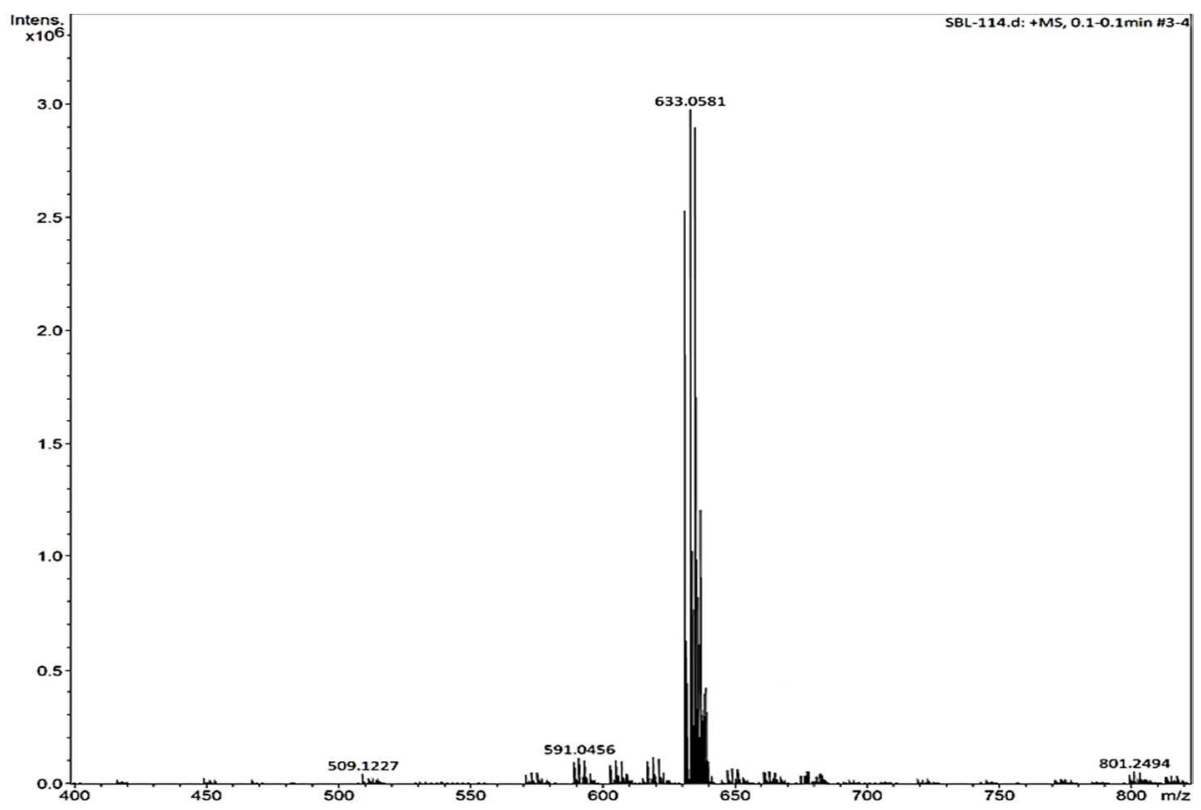

Figure S2. ESI-MS spectrum of $\mathbf{4 A}$. The peak at $\mathrm{m} / \mathrm{z} 633.05$ corresponds to $\left[\mathrm{C}_{21} \mathrm{H}_{31} \mathrm{~N}_{2} \mathrm{O}_{12} \mathrm{Zn}_{2}\right]^{+}$

3. Mass spectrum of $4 \mathrm{~B},\left[\mathrm{Zn}_{2}(\mathrm{Me}-\mathrm{dfp})(\mathrm{OAc})_{2}\right](\mathrm{OAc}) \cdot 2 \mathrm{H}_{2} \mathrm{O}$

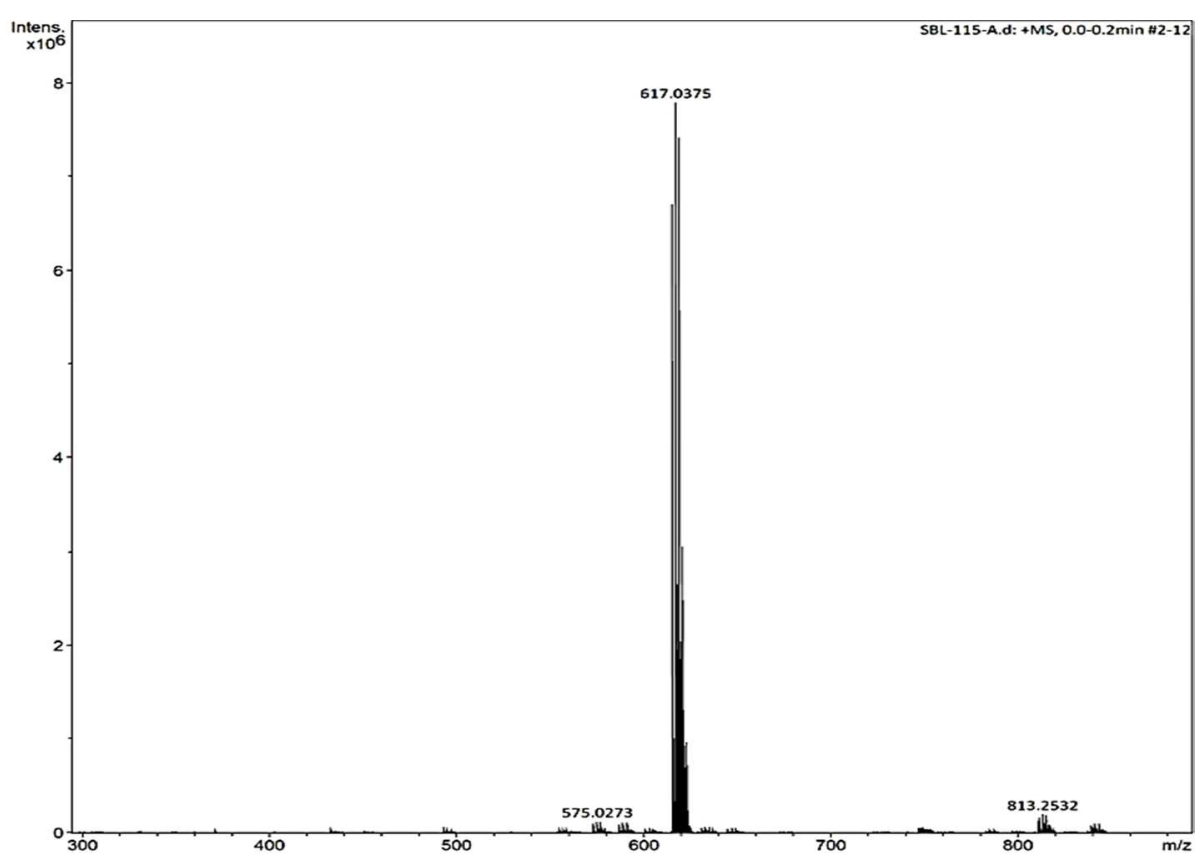

Figure S3. ESI-MS spectrum of 4B. The peak at $\mathrm{m} / \mathrm{z} 617.03$ corresponds to $\left[\mathrm{C}_{21} \mathrm{H}_{31} \mathrm{~N}_{2} \mathrm{O}_{11} \mathrm{Zn}_{2}\right]^{+}$ 


\section{Mass spectrum of $4 \mathrm{C},\left[\mathrm{Zn}_{2}(\mathrm{COOEt}-\mathrm{dfp})(\mathrm{OAc})_{2}\right](\mathrm{OAc}) \cdot 3 \mathrm{H}_{2} \mathrm{O}$}

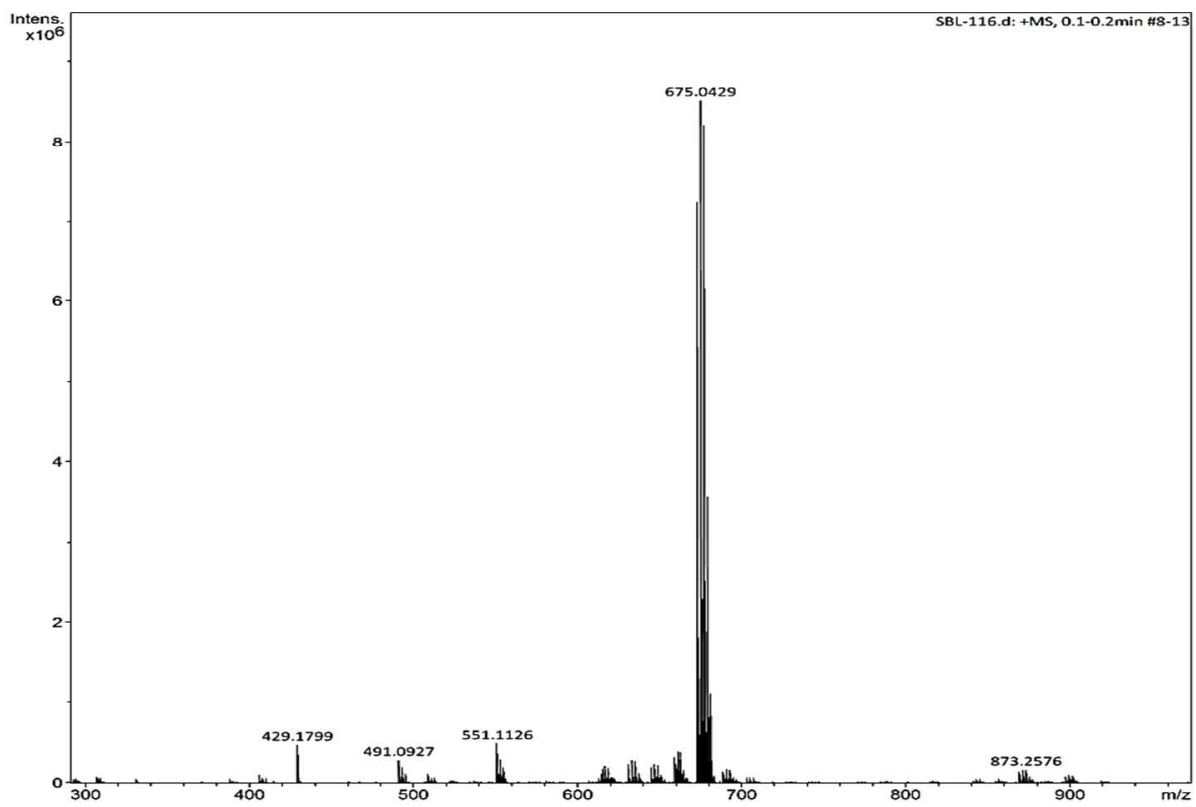

Figure S4. ESI-MS spectrum of $4 \mathrm{C}$. The peak at $\mathrm{m} / \mathrm{z} 675.04$ corresponds to $\left[\mathrm{C}_{23} \mathrm{H}_{33} \mathrm{~N}_{2} \mathrm{O}_{13} \mathrm{Zn}_{2}\right]^{+}$

5. Mass spectrum of $4 \mathrm{D},\left[\mathrm{Zn}_{2}(\mathrm{Br}-\mathrm{dfp})(\mathrm{OAc})_{2}\right](\mathrm{OAc}) \cdot \mathrm{H}_{2} \mathrm{O}$

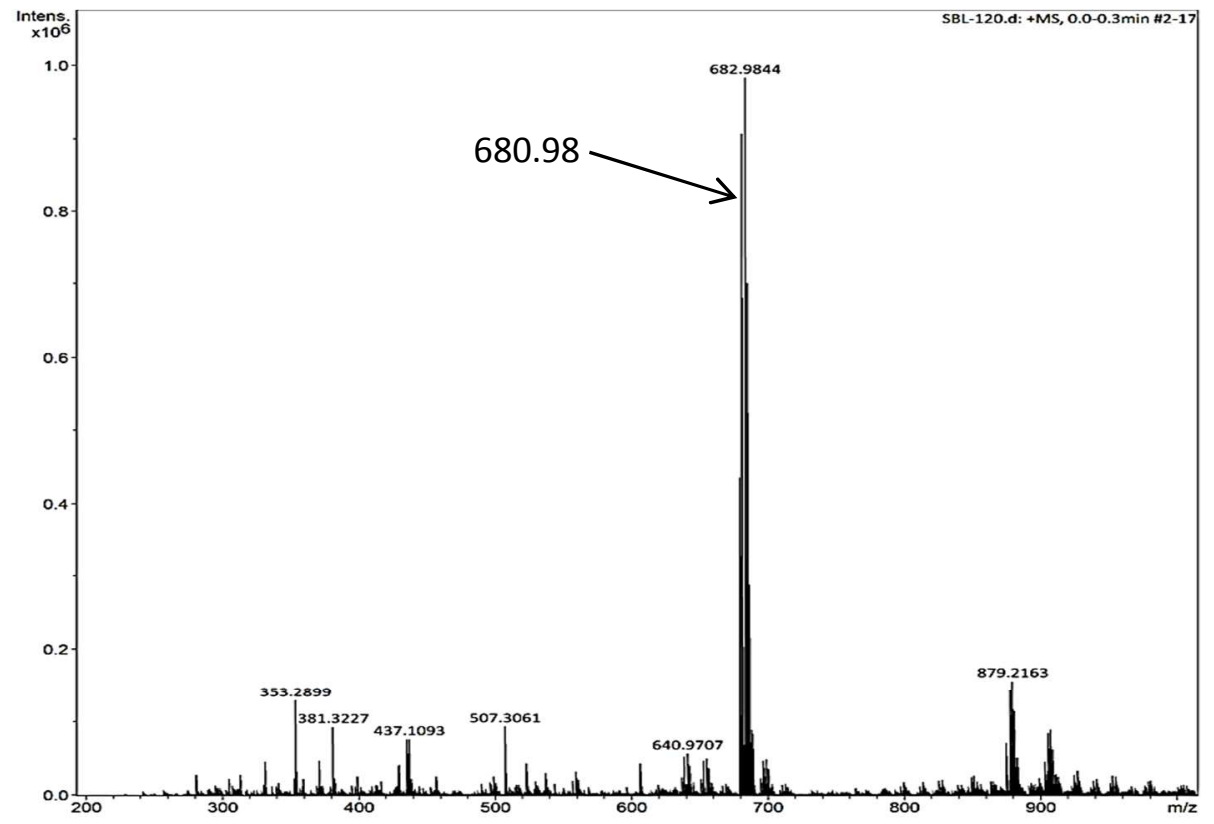

Figure S5. ESI-MS spectrum of 4D. The peak at $\mathrm{m} / \mathrm{z} 680.98$ corresponds to $\left[\mathrm{C}_{20} \mathrm{H}_{28} \mathrm{BrN}_{2} \mathrm{O}_{11} \mathrm{Zn}_{2}\right]^{+}$ 
Table S1. Selected bond lengths $(\AA)$ and bond angles $\left({ }^{\circ}\right)$ for complexes $4 \mathrm{~A}, 4 \mathrm{C}$ and 4D

\begin{tabular}{|c|c|c|c|}
\hline \multicolumn{4}{|l|}{$4 A$} \\
\hline \multicolumn{4}{|l|}{ Distances } \\
\hline $\mathrm{Zn}(1)-\mathrm{O}(7)$ & $1.961(2)$ & $\mathrm{Zn}(2)-\mathrm{O}(9)$ & $1.964(2)$ \\
\hline $\mathrm{Zn}(1)-\mathrm{O}(8)$ & $1.973(2)$ & $\mathrm{Zn}(2)-\mathrm{O}(6)$ & $1.985(2)$ \\
\hline $\mathrm{Zn}(1)-\mathrm{N}(1)$ & $2.019(2)$ & $\mathrm{Zn}(2)-\mathrm{N}(2)$ & $2.027(2)$ \\
\hline $\mathrm{Zn}(1)-\mathrm{O}(2)$ & $2.0694(19)$ & $\mathrm{Zn}(2)-\mathrm{O}(2)$ & $2.076(19)$ \\
\hline $\mathrm{Zn}(1)-\mathrm{O}(10)$ & $2.134(2)$ & $\mathrm{Zn}(2)-\mathrm{O}(5)$ & $2.157(2)$ \\
\hline \multicolumn{4}{|l|}{ Angles } \\
\hline $\mathrm{O}(7)-\mathrm{Zn}(1)-\mathrm{O}(8)$ & $113.05(11)$ & $\mathrm{O}(9)-\mathrm{Zn}(2)-\mathrm{N}(2)$ & $123.18(10)$ \\
\hline $\mathrm{O}(7)-\mathrm{Zn}(1)-\mathrm{N}(1)$ & $118.72(10)$ & $\mathrm{O}(6)-\mathrm{Zn}(2)-\mathrm{N}(2)$ & $124.47(10)$ \\
\hline $\mathrm{O}(8)-\mathrm{Zn}(1)-\mathrm{N}(1)$ & $126.89(9)$ & $\mathrm{O}(9)-\mathrm{Zn}(2)-\mathrm{O}(2)$ & $99.11(9)$ \\
\hline $\mathrm{O}(7)-\mathrm{Zn}(1)-\mathrm{O}(2)$ & $95.92(9)$ & $\mathrm{O}(6)-\mathrm{Zn}(2)-\mathrm{O}(2)$ & $95.64(9)$ \\
\hline $\mathrm{O}(8)-\mathrm{Zn}(1)-\mathrm{O}(2)$ & 95.91(9) & $\mathrm{N}(2)-\mathrm{Zn}(2)-\mathrm{O}(2)$ & $89.80(8)$ \\
\hline $\mathrm{N}(1)-\mathrm{Zn}(1)-\mathrm{O}(2)$ & $90.00(8)$ & $\mathrm{O}(9)-\mathrm{Zn}(2)-\mathrm{O}(5)$ & $90.13(9)$ \\
\hline $\mathrm{O}(7)-\mathrm{Zn}(1)-\mathrm{O}(10)$ & $91.30(10)$ & $\mathrm{O}(6)-\mathrm{Zn}(2)-\mathrm{O}(5)$ & $86.68(9)$ \\
\hline $\mathrm{O}(8)-\mathrm{Zn}(1)-\mathrm{O}(10)$ & $88.39(9)$ & $\mathrm{N}(2)-\mathrm{Zn}(2)-\mathrm{O}(5)$ & $80.04(8)$ \\
\hline $\mathrm{N}(1)-\mathrm{Zn}(1)-\mathrm{O}(10)$ & $79.67(9)$ & $\mathrm{O}(2)-\mathrm{Zn}(2)-\mathrm{O}(5)$ & $168.96(8)$ \\
\hline $\mathrm{O}(2)-\mathrm{Zn}(1)-\mathrm{O}(10)$ & $169.37(8)$ & $\mathrm{Zn}(1)-\mathrm{O}(2)-\mathrm{Zn}(2)$ & $101.99(8)$ \\
\hline $\mathrm{O}(9)-\mathrm{Zn}(2)-\mathrm{O}(6)$ & $110.39(11)$ & & \\
\hline \multicolumn{4}{|l|}{$4 C$} \\
\hline \multicolumn{4}{|l|}{ Distances } \\
\hline $\mathrm{Zn}(2)-\mathrm{O}(7)$ & $1.966(4)$ & $\mathrm{Zn}(1)-\mathrm{O}(8)$ & $1.935(5)$ \\
\hline $\mathrm{Zn}(2)-\mathrm{O}(6)$ & $1.969(4)$ & $\mathrm{Zn}(1)-\mathrm{O}(5)$ & $1.969(4)$ \\
\hline $\mathrm{Zn}(2)-\mathrm{N}(2)$ & $2.026(4)$ & $\mathrm{Zn}(1)-\mathrm{N}(1)$ & $2.007(5)$ \\
\hline $\mathrm{Zn}(2)-\mathrm{O}(1)$ & $2.076(4)$ & $\mathrm{Zn}(1)-\mathrm{O}(1)$ & $2.077(4)$ \\
\hline $\mathrm{Zn}(2)-\mathrm{O}(9)$ & $2.113(4)$ & $\mathrm{Zn}(1)-\mathrm{O}(4)$ & $2.104(5)$ \\
\hline $\mathrm{Zn}(3)-\mathrm{O}(21)$ & $1.961(5)$ & $\mathrm{Zn}(4)-\mathrm{O}(19)$ & $1.962(5)$ \\
\hline $\mathrm{Zn}(3)-\mathrm{O}(18)$ & $1.961(4)$ & $\mathrm{Zn}(4)-\mathrm{O}(20)$ & $1.969(5)$ \\
\hline $\mathrm{Zn}(3)-\mathrm{N}(3)$ & $2.029(4)$ & $\mathrm{Zn}(4)-\mathrm{N}(4)$ & $2.009(5)$ \\
\hline $\mathrm{Zn}(3)-\mathrm{O}(14)$ & $2.080(4)$ & $\mathrm{Zn}(4)-\mathrm{O}(14)$ & $2.085(4)$ \\
\hline $\mathrm{Zn}(3)-\mathrm{O}(17)$ & $2.128(4)$ & $\mathrm{Zn}(4)-\mathrm{O}(22)$ & $2.109(5)$ \\
\hline \multicolumn{4}{|l|}{ Angles } \\
\hline $\mathrm{O}(7)-\mathrm{Zn}(2)-\mathrm{O}(6)$ & $116.8(19)$ & $\mathrm{O}(8)-\mathrm{Zn}(1)-\mathrm{N}(1)$ & $117.4(2)$ \\
\hline $\mathrm{O}(7)-\mathrm{Zn}(2)-\mathrm{N}(2)$ & $124.5(19)$ & $\mathrm{O}(5)-\mathrm{Zn}(1)-\mathrm{N}(1)$ & $122.6(2)$ \\
\hline $\mathrm{O}(6)-\mathrm{Zn}(2)-\mathrm{N}(2)$ & $117.88(19)$ & $\mathrm{O}(8)-\mathrm{Zn}(1)-\mathrm{O}(1)$ & $97.02(19)$ \\
\hline $\mathrm{O}(7)-\mathrm{Zn}(2)-\mathrm{O}(1)$ & $94.12(17)$ & $\mathrm{O}(5)-\mathrm{Zn}(1)-\mathrm{O}(1)$ & $96.01(18)$ \\
\hline $\mathrm{O}(6)-\mathrm{Zn}(2)-\mathrm{O}(1)$ & $95.14(18)$ & $\mathrm{N}(1)-\mathrm{Zn}(1)-\mathrm{O}(1)$ & $89.46(17)$ \\
\hline $\mathrm{N}(2)-\mathrm{Zn}(2)-\mathrm{O}(1)$ & $89.64(17)$ & $\mathrm{O}(8)-\mathrm{Zn}(1)-\mathrm{O}(4)$ & $90.1(2)$ \\
\hline $\mathrm{O}(7)-\mathrm{Zn}(2)-\mathrm{O}(9)$ & $88.29(17)$ & $\mathrm{O}(5)-\mathrm{Zn}(1)-\mathrm{O}(4)$ & $89.1(2)$ \\
\hline $\mathrm{O}(6)-\mathrm{Zn}(2)-\mathrm{O}(9)$ & 91.99(19) & $\mathrm{N}(1)-\mathrm{Zn}(1)-\mathrm{O}(4)$ & $78.6(2)$ \\
\hline $\mathrm{N}(2)-\mathrm{Zn}(2)-\mathrm{O}(9)$ & $81.39(17)$ & $\mathrm{O}(1)-\mathrm{Zn}(1)-\mathrm{O}(4)$ & $168.0(2)$ \\
\hline $\mathrm{O}(1)-\mathrm{Zn}(2)-\mathrm{O}(9)$ & $170.44(16)$ & $\mathrm{O}(19)-\mathrm{Zn}(4)-\mathrm{O}(20)$ & $119.5(2)$ \\
\hline $\mathrm{O}(21)-\mathrm{Zn}(3)-\mathrm{O}(18)$ & $117.7(2)$ & $\mathrm{O}(19)-\mathrm{Zn}(4)-\mathrm{N}(4)$ & $124.3(2)$ \\
\hline $\mathrm{O}(21)-\mathrm{Zn}(3)-\mathrm{N}(3)$ & $114.68(19)$ & $\mathrm{O}(20)-\mathrm{Zn}(4)-\mathrm{N}(4)$ & $115.1(2)$ \\
\hline $\mathrm{O}(18)-\mathrm{Zn}(3)-\mathrm{N}(3)$ & $126.6(2)$ & $\mathrm{O}(19)-\mathrm{Zn}(4)-\mathrm{O}(14)$ & $95.56(18)$ \\
\hline $\mathrm{O}(21)-\mathrm{Zn}(3)-\mathrm{O}(14)$ & $95.19(18)$ & $\mathrm{O}(20)-\mathrm{Zn}(4)-\mathrm{O}(14)$ & $95.07(18)$ \\
\hline $\mathrm{O}(18)-\mathrm{Zn}(3)-\mathrm{O}(14)$ & $95.27(17)$ & $\mathrm{N}(4)-\mathrm{Zn}(4)-\mathrm{O}(14)$ & $89.83(17)$ \\
\hline $\mathrm{N}(3)-\mathrm{Zn}(3)-\mathrm{O}(14)$ & $89.46(16)$ & $\mathrm{O}(19)-\mathrm{Zn}(4)-\mathrm{O}(22)$ & $86.8(2)$ \\
\hline $\mathrm{O}(21)-\mathrm{Zn}(3)-\mathrm{O}(17)$ & $92.47(19)$ & $\mathrm{O}(20)-\mathrm{Zn}(4)-\mathrm{O}(22)$ & $94.0(2)$ \\
\hline $\mathrm{O}(18)-\mathrm{Zn}(3)-\mathrm{O}(17)$ & $87.22(17)$ & $\mathrm{N}(4)-\mathrm{Zn}(4)-\mathrm{O}(22)$ & $79.21(19)$ \\
\hline $\mathrm{N}(3)-\mathrm{Zn}(3)-\mathrm{O}(17)$ & $81.07(17)$ & $\mathrm{O}(14)-\mathrm{Zn}(4)-\mathrm{O}(22)$ & $168.02(19)$ \\
\hline $\mathrm{O}(14)-\mathrm{Zn}(3)-\mathrm{O}(17)$ & $169.69(16)$ & $\mathrm{Zn}(2)-\mathrm{O}(1)-\mathrm{Zn}(1)$ & $100.52(16)$ \\
\hline $\mathrm{O}(8)-\mathrm{Zn}(1)-\mathrm{O}(5)$ & $118.5(2)$ & $\mathrm{Zn}(3)-\mathrm{O}(14)-\mathrm{Zn}(4)$ & $100.15(16)$ \\
\hline
\end{tabular}


4D

Distances

$\mathrm{Zn}(1)-\mathrm{O}(9)$

$\mathrm{Zn}(1)-\mathrm{O}(10)$

$\mathrm{Zn}(1)-\mathrm{N}(1)$

$\mathrm{Zn}(1)-\mathrm{O}(1)$

$\mathrm{Zn}(1)-\mathrm{O}(4)$

\section{Angles}

$\mathrm{O}(11)-\mathrm{Zn}(2)-\mathrm{O}(8)$

$\mathrm{O}(11)-\mathrm{Zn}(2)-\mathrm{N}(2)$

$\mathrm{O}(8)-\mathrm{Zn}(2)-\mathrm{N}(2)$

$\mathrm{O}(11)-\mathrm{Zn}(2)-\mathrm{O}(7)$

$\mathrm{O}(8)-\mathrm{Zn}(2)-\mathrm{O}(7)$

$\mathrm{N}(2)-\mathrm{Zn}(2)-\mathrm{O}(7)$

$\mathrm{O}(11)-\mathrm{Zn}(2)-\mathrm{O}(1)$

$\mathrm{O}(8)-\mathrm{Zn}(2)-\mathrm{O}(1)$

$\mathrm{N}(2)-\mathrm{Zn}(2)-\mathrm{O}(1)$

$\mathrm{O}(7)-\mathrm{Zn}(2)-\mathrm{O}(1)$

$\mathrm{O}(9)-\mathrm{Zn}(1)-\mathrm{O}(10)$
$1.981(4)$
$1.981(4)$
$2.023(4)$
$2.053(3)$
$2.133(4)$

119.0(2)

119.99(17)

120.2(2)

91.09(17)

$88.19(16)$

$82.20(15)$

94.56(16)

94.13(15)

89.94(14)

171.90(14)

119.64(19)
$\mathrm{Zn}(2)-\mathrm{O}(11)$

$\mathrm{Zn}(2)-\mathrm{O}(8)$

$\mathrm{Zn}(2)-\mathrm{N}(2)$

$\mathrm{Zn}(2)-\mathrm{O}(7)$

$\mathrm{Zn}(2)-\mathrm{O}(1)$

$\mathrm{O}(9)-\mathrm{Zn}(1)-\mathrm{N}(1)$

$\mathrm{O}(10)-\mathrm{Zn}(1)-\mathrm{N}(1)$

$\mathrm{O}(9)-\mathrm{Zn}(1)-\mathrm{O}(1)$

$\mathrm{O}(10)-\mathrm{Zn}(1)-\mathrm{O}(1)$

$\mathrm{N}(1)-\mathrm{Zn}(1)-\mathrm{O}(1)$

$\mathrm{O}(9)-\mathrm{Zn}(1)-\mathrm{O}(4)$

$\mathrm{O}(10)-\mathrm{Zn}(1)-\mathrm{O}(4)$

$\mathrm{N}(1)-\mathrm{Zn}(1)-\mathrm{O}(4)$

$\mathrm{O}(1)-\mathrm{Zn}(1)-\mathrm{O}(4)$

$\mathrm{Zn}(1)-\mathrm{O}(1)-\mathrm{Zn}(2)$
$1.971(4)$

$1.974(4)$

$2.013(4)$

$2.055(3)$

$2.078(3)$

$119.4(2)$

$119.82(17)$

94.83(16)

$95.02(15)$

$90.94(15)$

91.97(19)

$87.32(18)$

$79.95(16)$

$170.52(15)$

$101.45(14)$

\section{Photophysical properties of complexes 4A-4D}

\subsection{Fluorescence spectra}

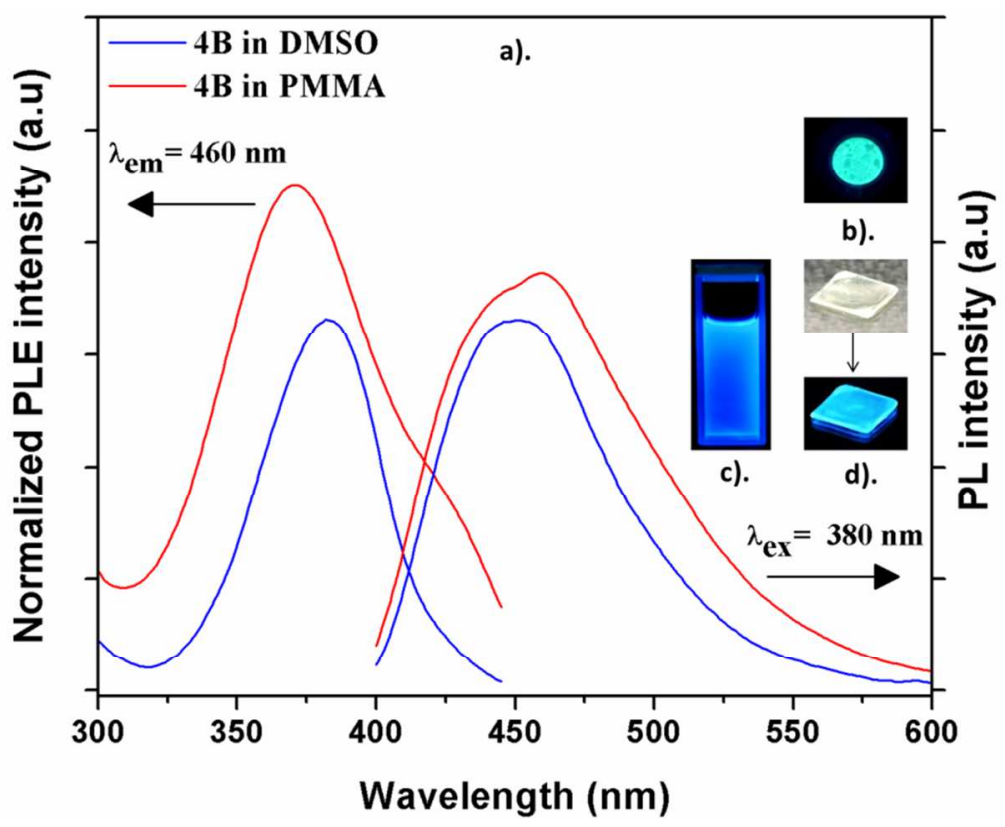

Figure S6. a) PL excitation (PLE) and emission (PL) spectra (left and right panels, respectively) of complex 4B in DMSO and in PMMA. The PL and PLE spectra were excited and recorded at $380 \mathrm{~nm}$ and $460 \mathrm{~nm}$, respectively. b) Solid state image of 4B in $\mathrm{BaSO}_{4}$ under $365 \mathrm{~nm}$ irradiation. c) 4B in DMSO UV irradiation (365 nm). d) PMMA sheet containing 4B under visible light (above) and under $365 \mathrm{~nm}$ irradiation (below). 


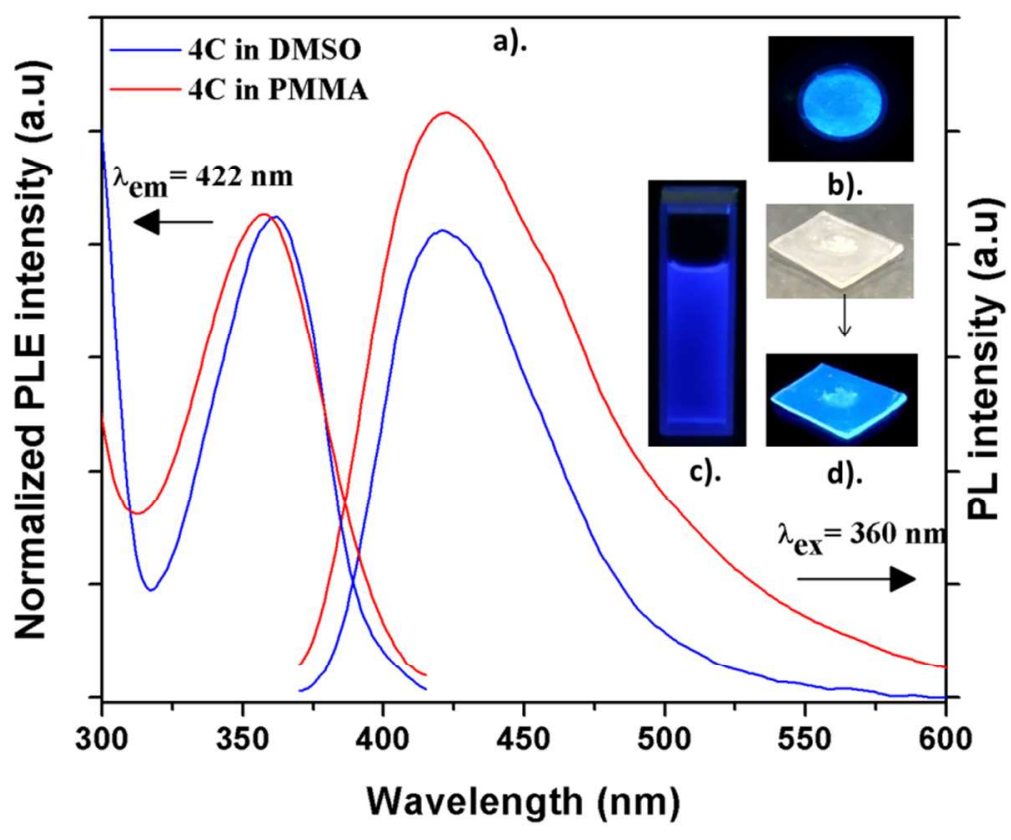

Figure S7. a) PL excitation (PLE) and emission (PL) spectra (left and right panels, respectively) of complex 4C in DMSO and in PMMA. The PL and PLE spectra were excited and recorded at $360 \mathrm{~nm}$ and $422 \mathrm{~nm}$ respectively. b) Solid state image of $\mathbf{4 C}$ in $\mathrm{BaSO}_{4}$ under $365 \mathrm{~nm}$ irradiation. c) $4 \mathrm{C}$ in DMSO under UV irradiation (365 nm). d) PMMA sheet containing 4C under visible light (above) and under $365 \mathrm{~nm}$ irradiation (below).

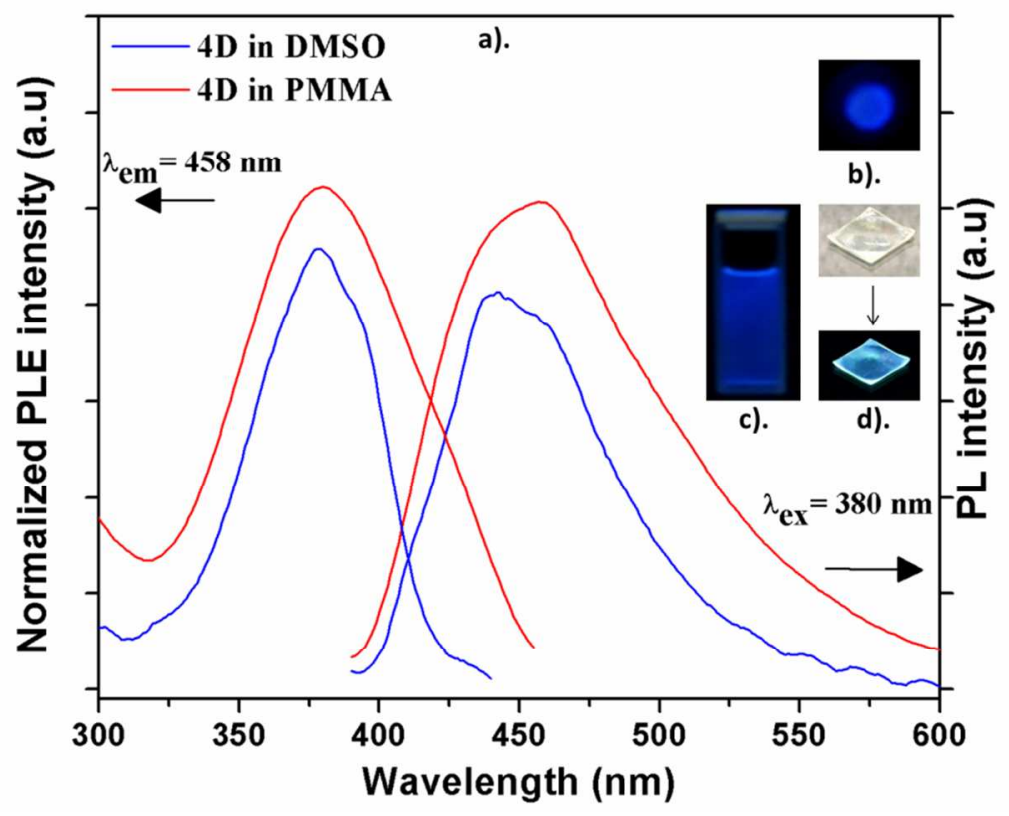

Figure S8. a) PL excitation (PLE) and emission (PL) spectra (left and right panels, respectively) of complex 4D in DMSO and in PMMA. The PL and PLE spectra were excited and recorded at $380 \mathrm{~nm}$ and $458 \mathrm{~nm}$, respectively. b) Solid state image of 4D in $\mathrm{BaSO}_{4}$ under $365 \mathrm{~nm}$ irradiation. c) DMSO containing 4D under UV irradiation (365 nm) d) PMMA sheet containing 4D under visible light (above) and under $365 \mathrm{~nm}$ irradiation (below). 


\subsection{Absorption spectra of complexes 4A-4D}
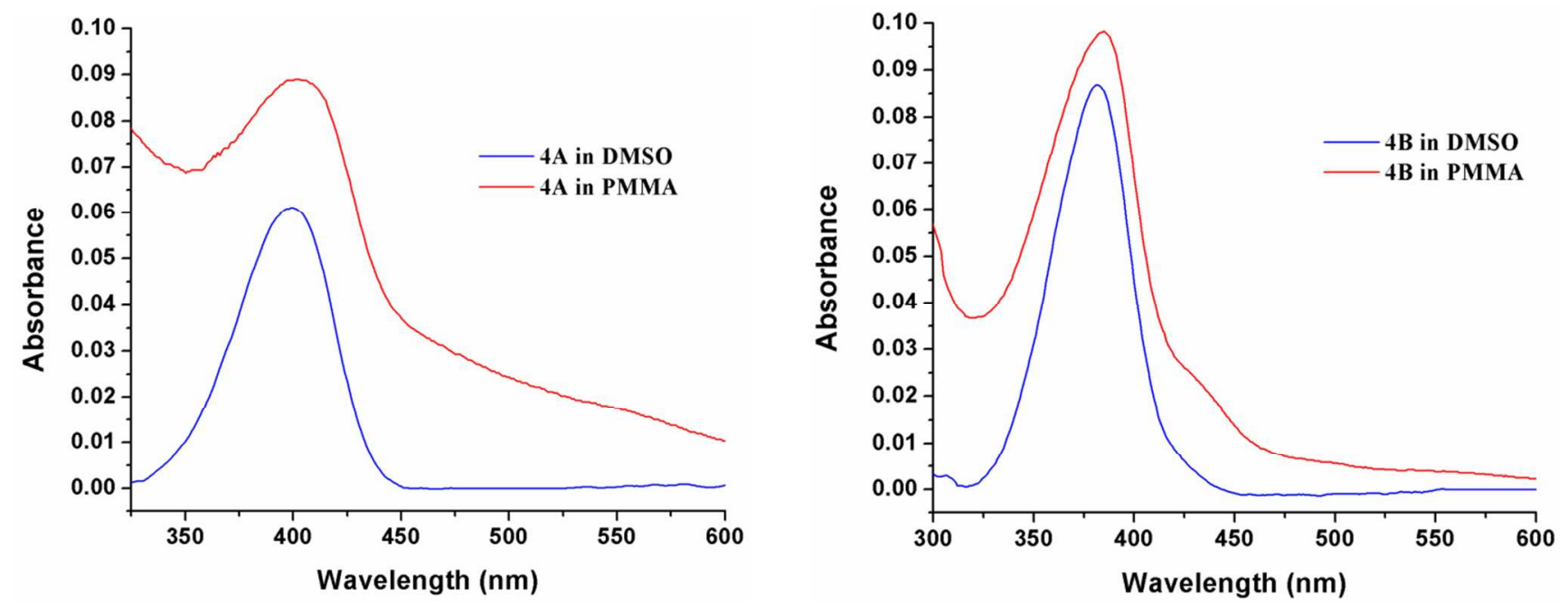

Figure S9. Absorption spectra of 4A and 4B in DMSO $(10 \mu \mathrm{M})$ and in PMMA (abs $\leq 0.1)$.
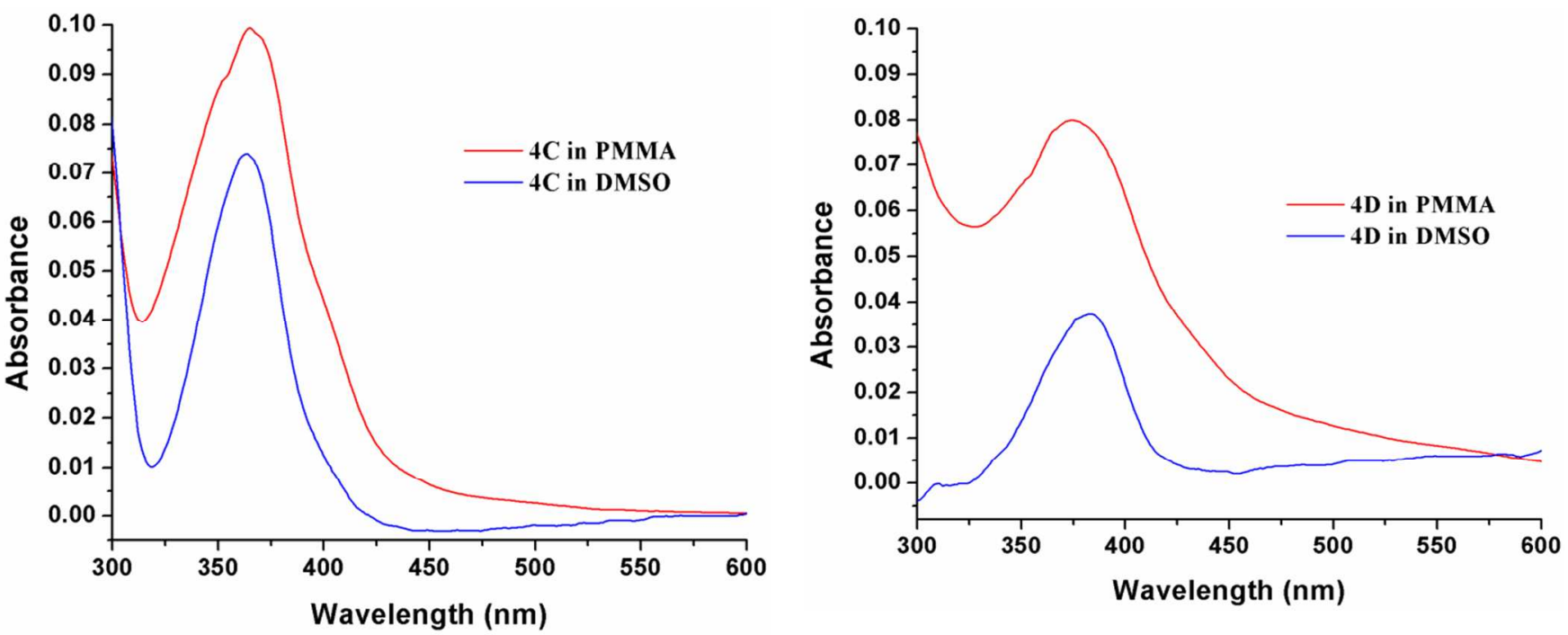

Figure S10. Absorption spectra of $\mathbf{4 C}$ and $4 \mathrm{D}$ in DMSO $(10 \mu \mathrm{M})$ and in PMMA (abs $\leq 0.1)$. 


\subsection{Molar absorptivity of complexes 4A-4D}
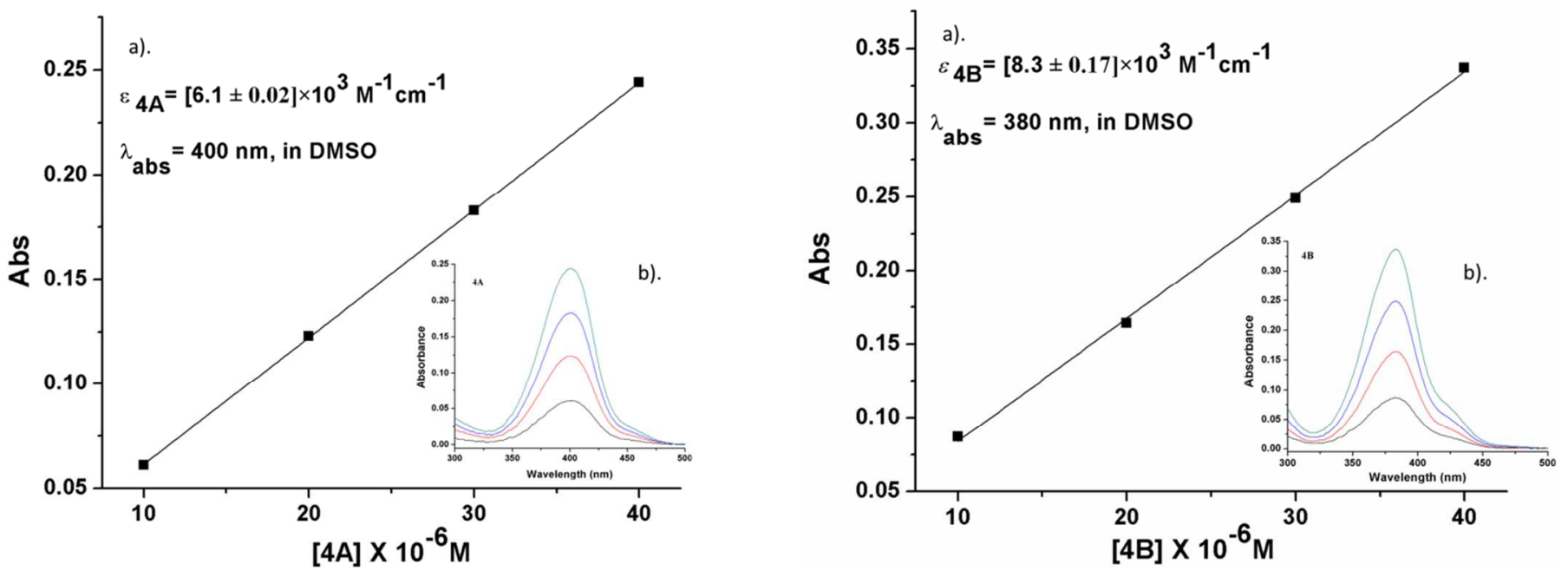

Figure S11. Left: (a) Beer-Lambert plot and (b) absorption spectrum of 4A in DMSO. Right: (a) Beer-Lambert plot and (b) absorption spectrum of $\mathbf{4 B}$ in DMSO.
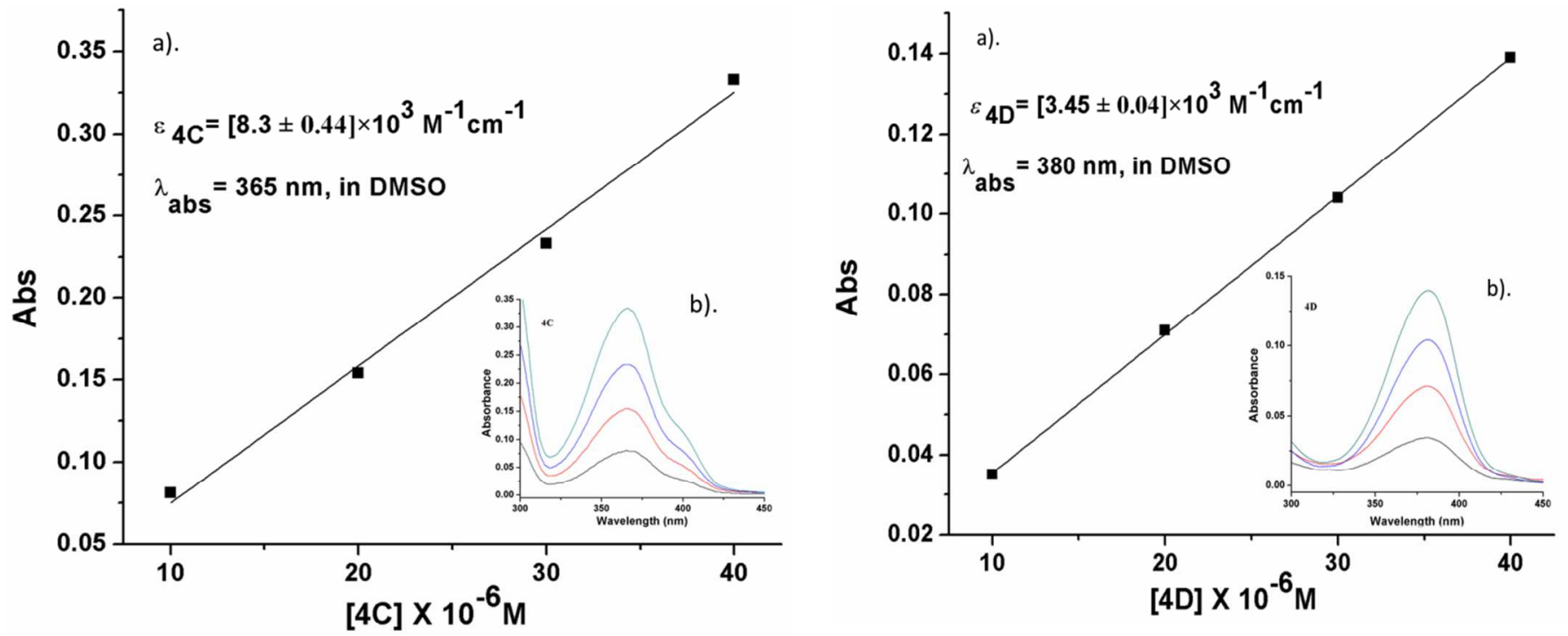

Figure S12. Left: (a) Beer-Lambert plot and (b) absorption spectrum of $4 \mathrm{C}$ in DMSO. Right: (a) Beer-Lambert plot and (b) absorption spectrum of 4D in DMSO. 


\subsection{Fluorescence lifetime measurements on complexes $4 \mathrm{~A}-4 \mathrm{D}$}

Complexes 4A - 4D exhibited tri-exponential decay in both solution and in PMMA matrix.
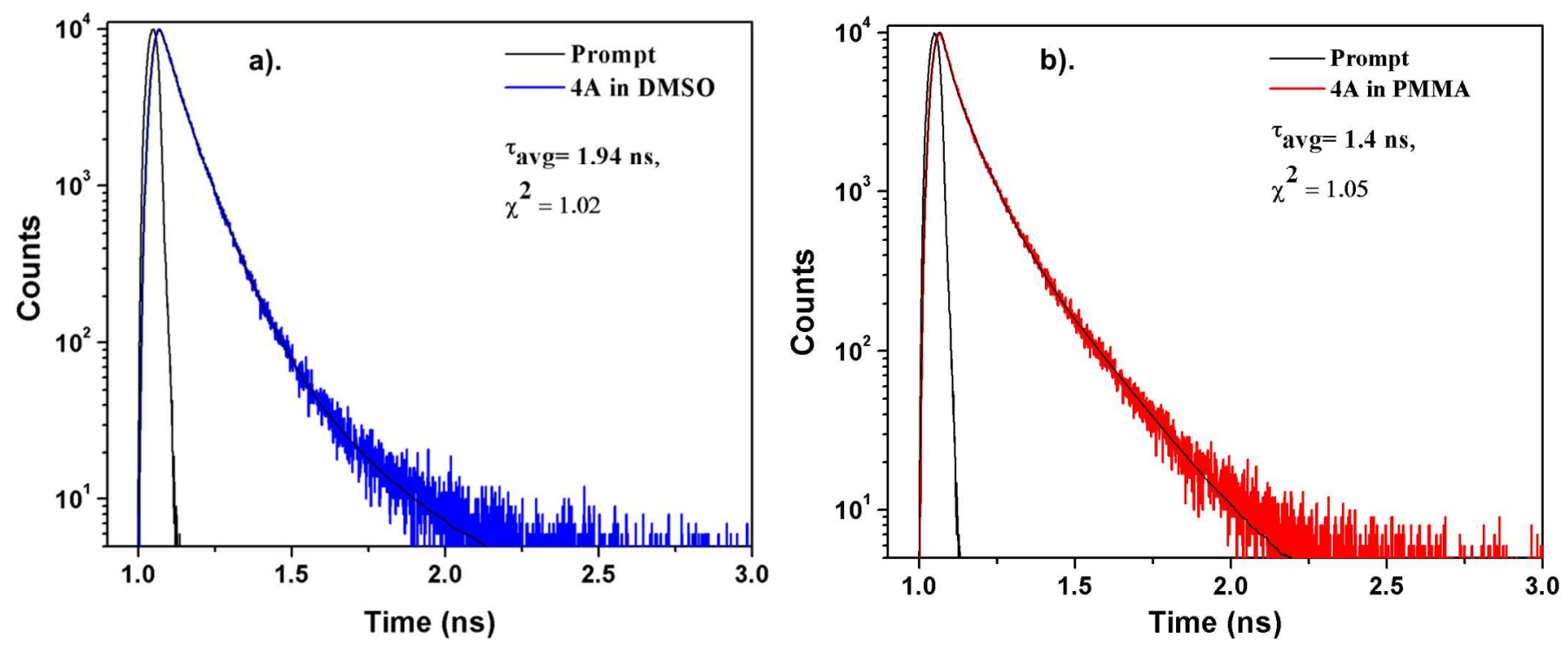

Figure S13. Decay data of 4A a) in DMSO and b) in PMMA.
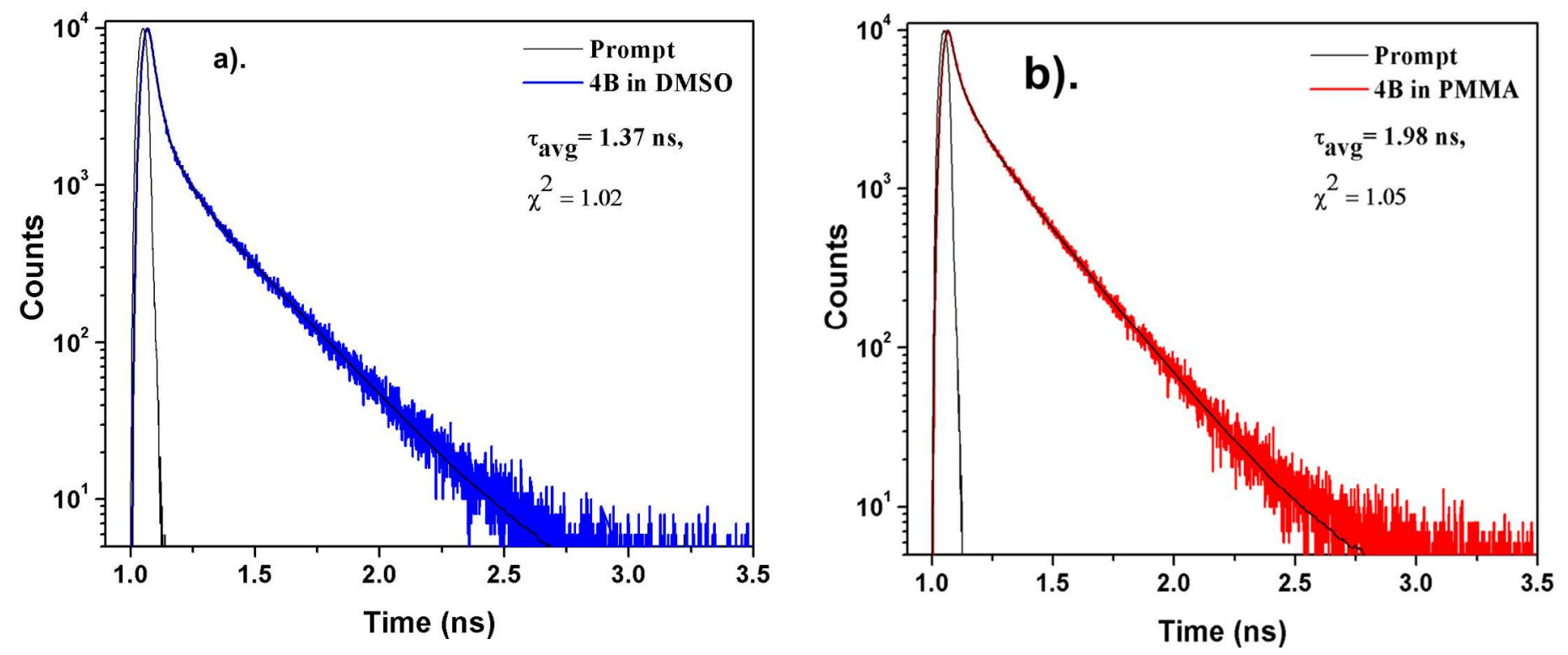

Figure S14. Decay data of $4 \mathrm{~B}$ a) in DMSO and b) in PMMA. 

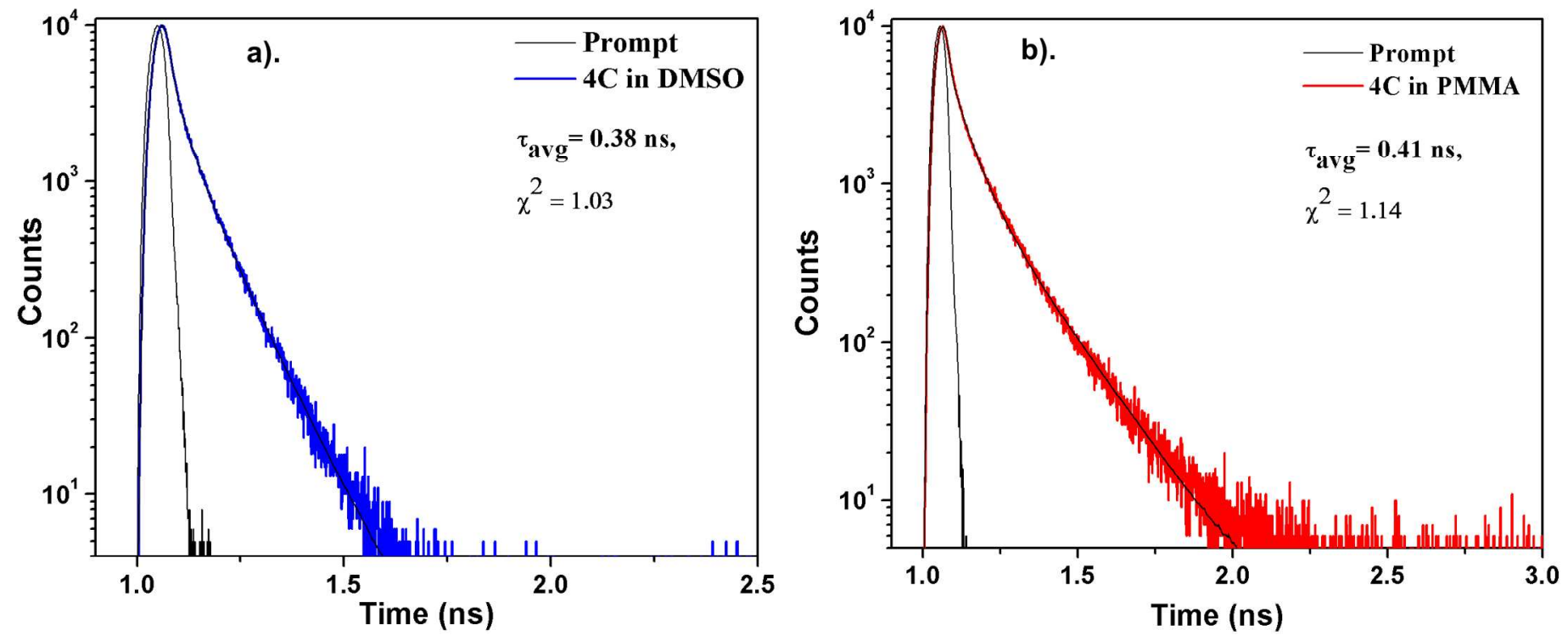

Figure S15. Decay data of $\mathbf{4 C}$ a) in DMSO and b) in PMMA.
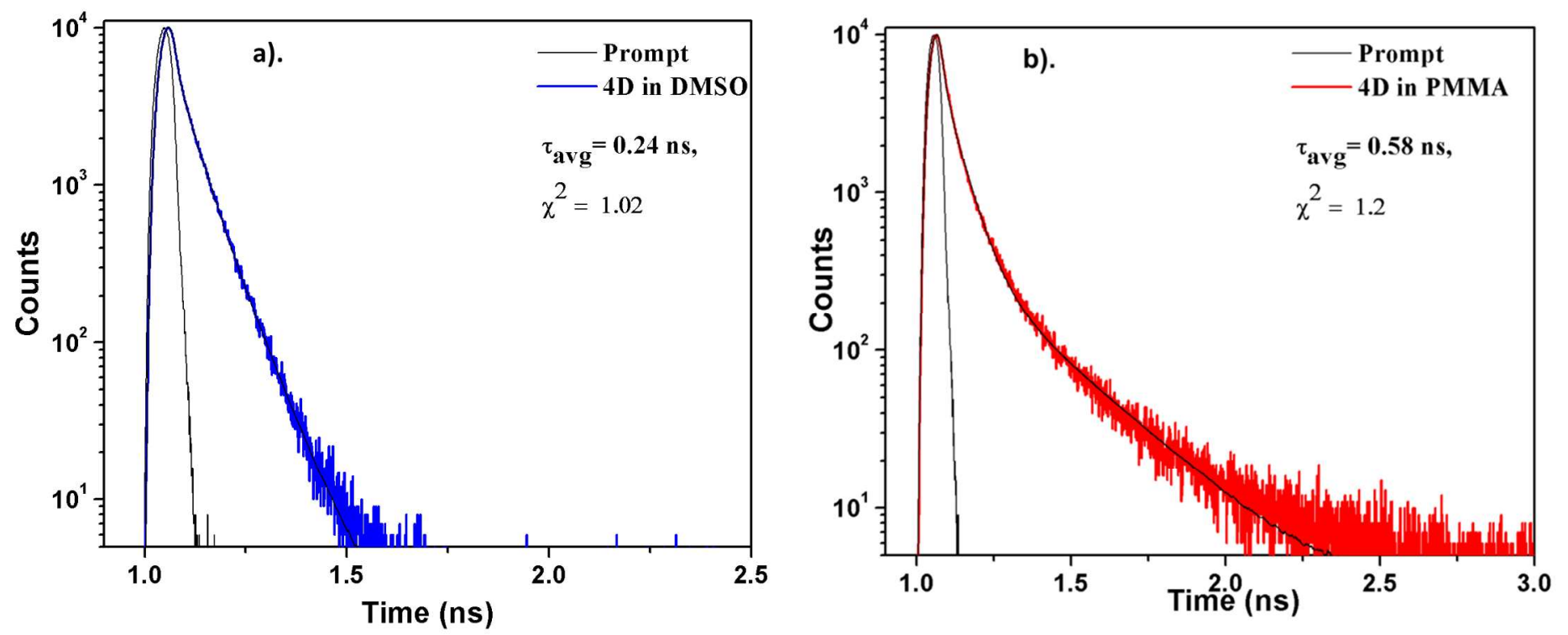

Figure S16. Decay data of 4D a) in DMSO and b) in PMMA. 
7. Electrochemical properties of ligands 3A-3D

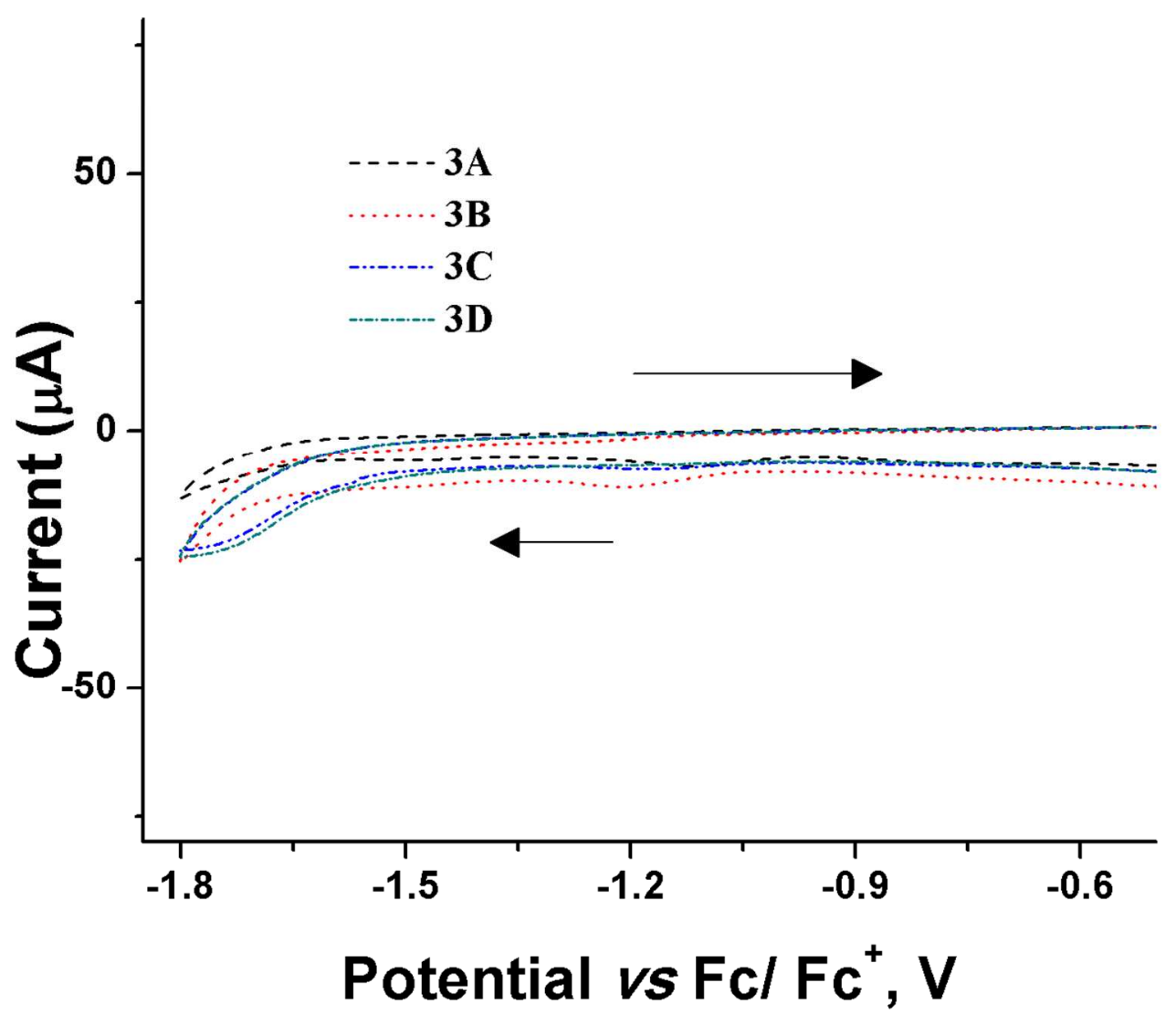

Figure S17. Cyclic voltammograms of $5 \times 10^{-3} \mathrm{M}$ solutions of $\mathbf{3 A}, \mathbf{3 B}, \mathbf{3 C}$ and $\mathbf{3 D}$ in DMSO containing $0.1 \mathrm{M} n$ $\mathrm{Bu}_{4} \mathrm{NPF}_{6}$ : scan rate $-100 \mathrm{mVs}^{-1}$; working electrode - glassy carbon; reference electrode $-\mathrm{Ag} / \mathrm{AgCl}$. 
8. Catalytic activities of complexes 4A-4D

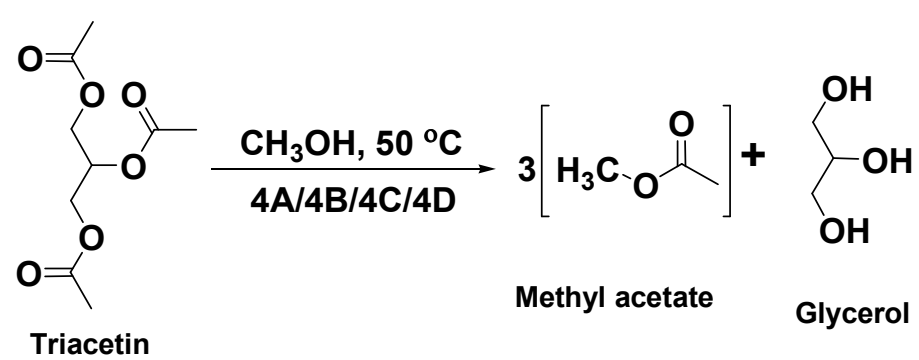

Scheme S2. Transesterification of triacetin with methanol catalyzed by complexes 4A-4D 


\section{ESI-MS studies to elucidate a plausible mechanism for transesterification reactions catalyzed by complexes $4 A-4 D$}

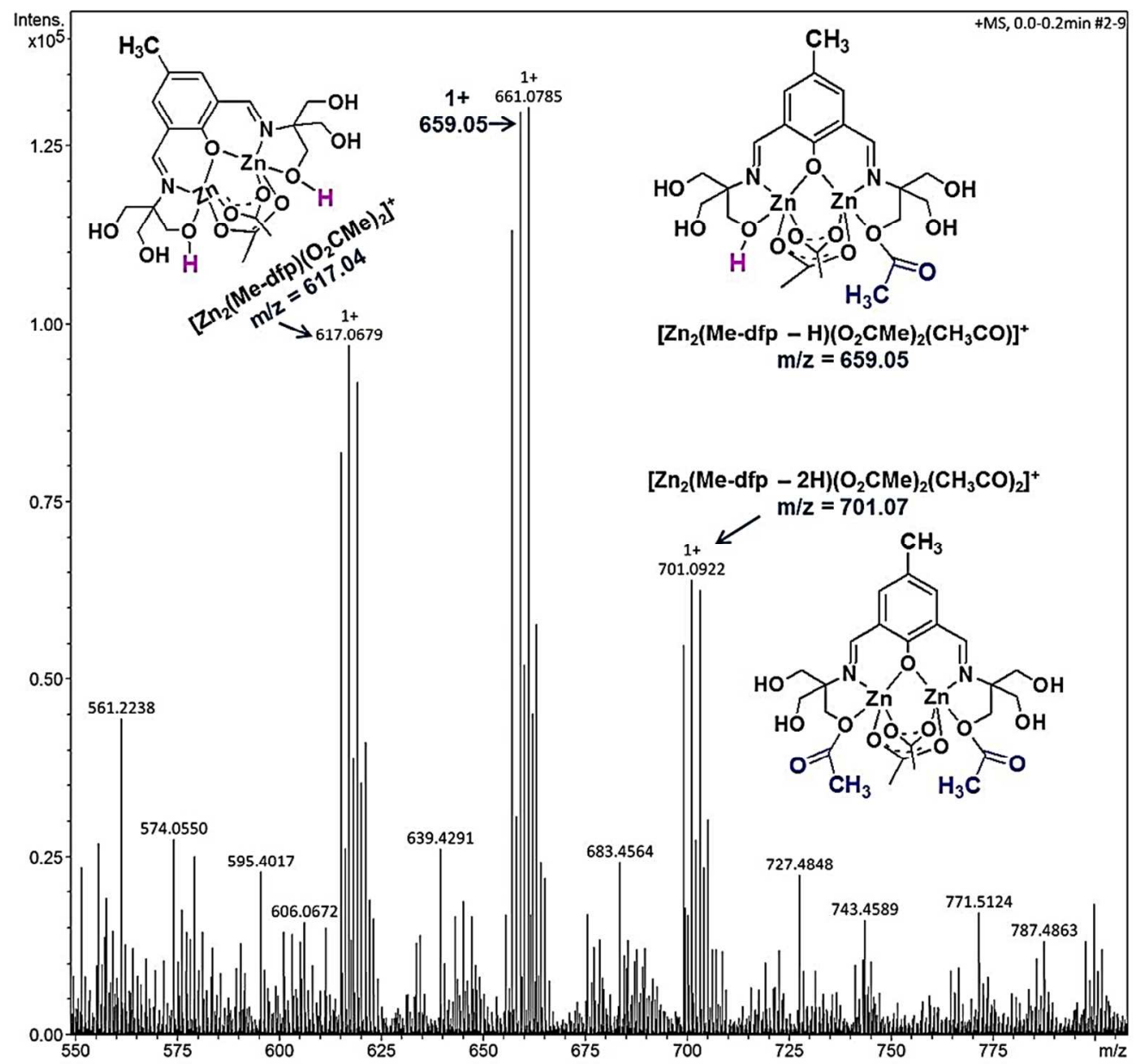

Figure S18. Mass spectrum of the reaction mixture of the transesterification reaction involving phenyl acetate, methanol and complex 4B as catalyst showing the formation of acyl intermediates species. 


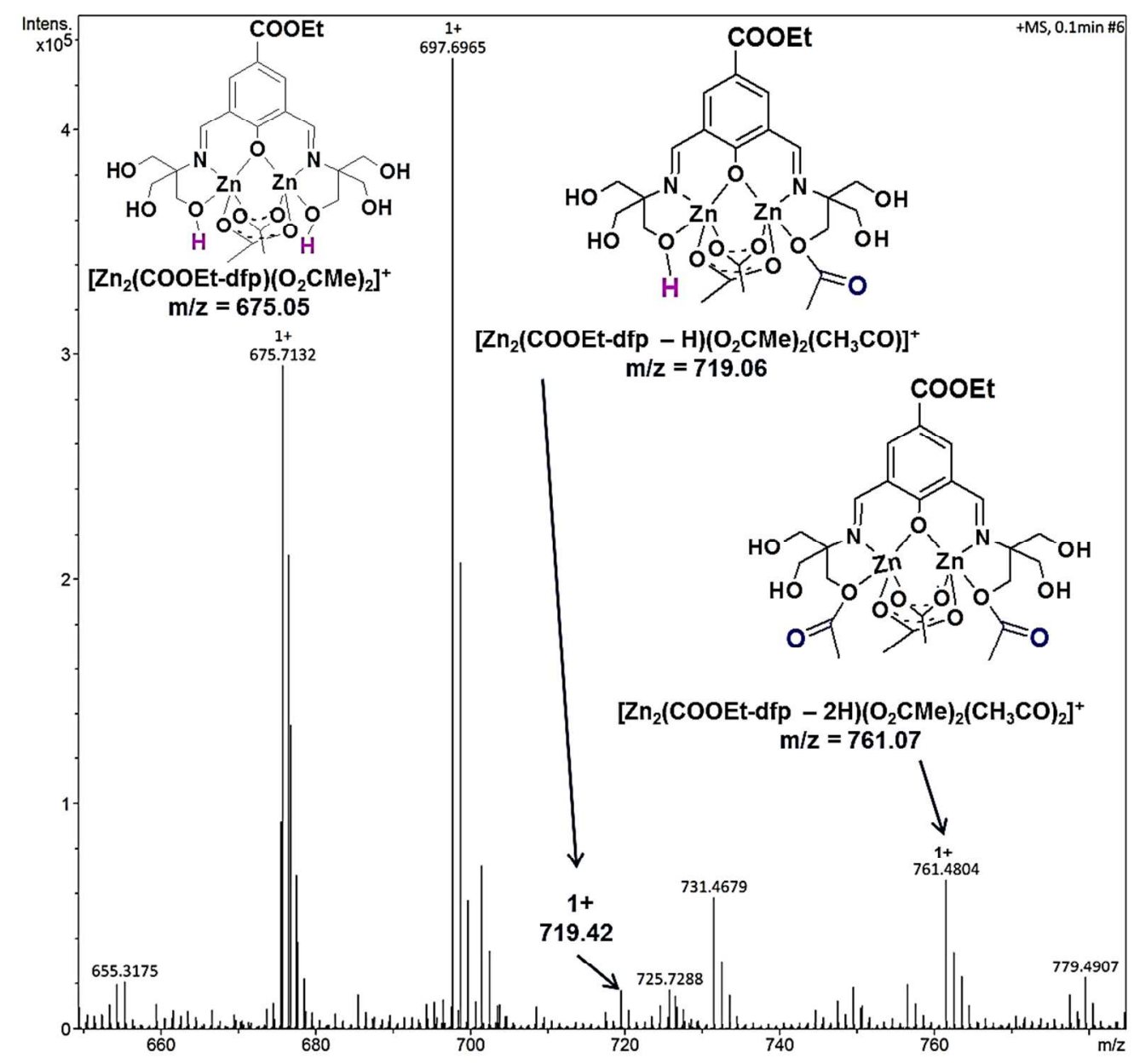

Figure S19. Mass spectrum of the reaction mixture of the transesterification reaction involving phenyl acetate, methanol and complex $\mathbf{4 C}$ as catalyst showing the formation of acyl intermediates species. 


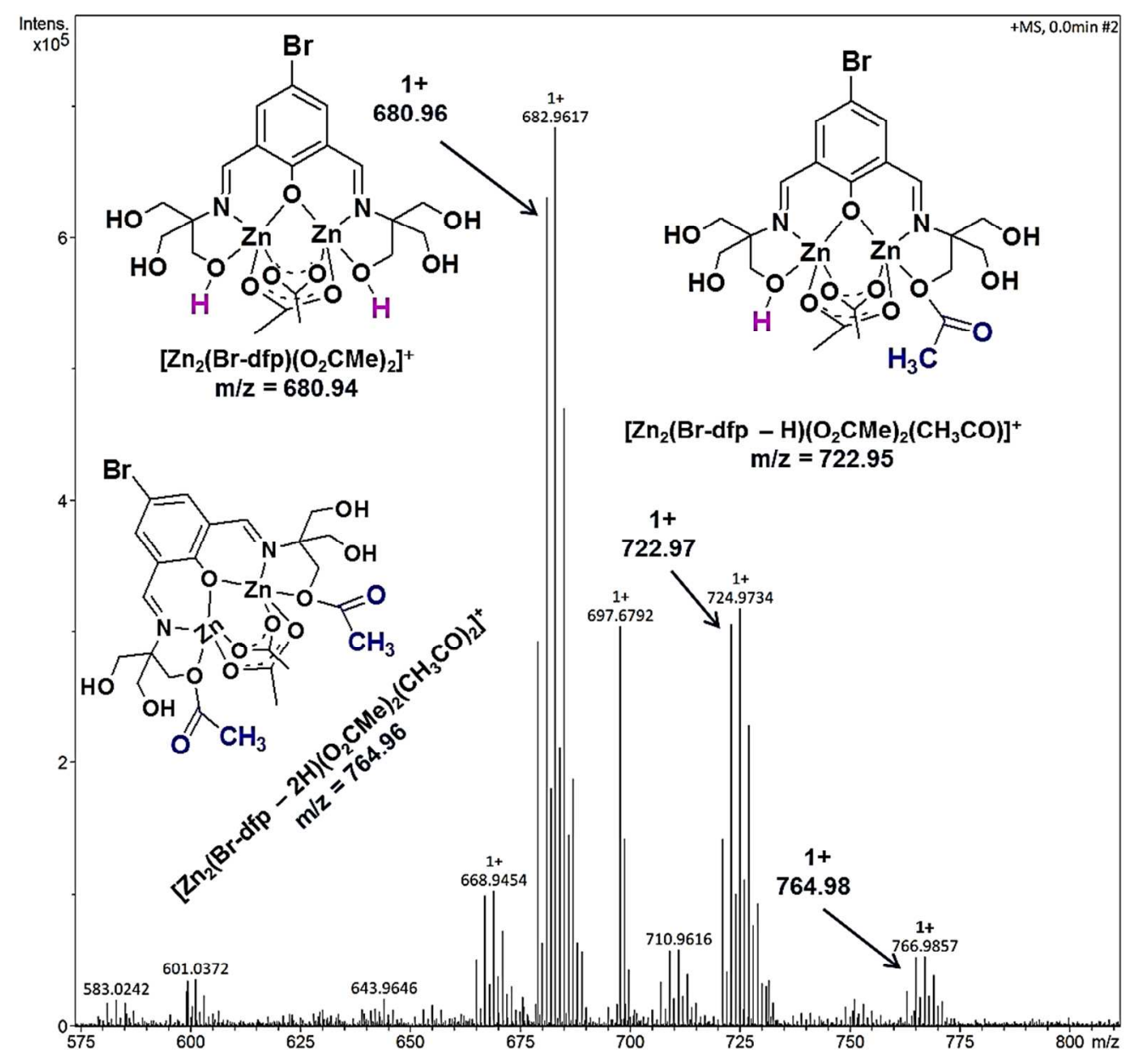

Figure S20. Mass spectrum of the reaction mixture of the transesterification reaction involving phenyl acetate, methanol and complex 4D as catalyst showing the formation of acyl intermediates species. 
10. GC conditions employed for the determination of transesterification products: (i) ethyl acetate (EA), (ii) isopropyl acetate (IA), (iii) butyl acetate (BuA), (iv) hexyl acetate (HA) and (v) benzyl acetate (BnA)

\section{GC Agilent 7890A series, Split/ Splitless inlet (MMI inlet)}

\begin{tabular}{lll}
\hline Condition & IA, BuA and BnA & EA and HA \\
\hline Inlet temperature & $140{ }^{\circ} \mathrm{C}$ for 4 min & $130{ }^{\circ} \mathrm{C}$ for 4 min \\
& $40{ }^{\circ} \mathrm{C} / \min$ to $220{ }^{\circ} \mathrm{C}$ for $1 \mathrm{~min}$ & $45{ }^{\circ} \mathrm{C} / \mathrm{min}$ to $225{ }^{\circ} \mathrm{C}$ for $5 \mathrm{~min}$ \\
Injecting volume & $1 \mu \mathrm{l}$ & $1 \mu \mathrm{l}$ \\
Splitless flow & $40 \mathrm{ml} / \mathrm{min}$ & $40 \mathrm{ml} / \mathrm{min}$ \\
Column & $\mathrm{HP}-5$ column $(5 \%$ phenyl methyl & $\mathrm{HP}-5$ column $(5 \%$ phenyl methyl \\
& siloxan, $30 \mathrm{~m} \times 320 \mu \mathrm{M} \times 0.25 \mu \mathrm{M})$ & siloxan, $30 \mathrm{~m} \times 320 \mu \mathrm{M} \times 0.25 \mu \mathrm{M})$ \\
Column 2 flow & $\mathrm{N}_{2}$ at $3 \mathrm{ml} / \min$ constant flow & $\mathrm{N}_{2}$ at $3 \mathrm{ml} / \mathrm{min}$ constant flow \\
Column temperature & $35^{\circ} \mathrm{C}$ & $35^{\circ} \mathrm{C}$ \\
& $20{ }^{\circ} \mathrm{C} / \min$ to $135^{\circ} \mathrm{C}$ & $15{ }^{\circ} \mathrm{C} / \min$ to $125{ }^{\circ} \mathrm{C}$ for $0.1 \mathrm{~min}$ \\
& $45^{\circ} \mathrm{C} / \min$ to $225^{\circ} \mathrm{C}$ & $25{ }^{\circ} \mathrm{C} / \min$ to $220^{\circ} \mathrm{C}$ for $0.1 \mathrm{~min}$ \\
Flame ionization detector $(\mathbf{F I D})$ & $300^{\circ} \mathrm{C}$ & $300{ }^{\circ} \mathrm{C}$ \\
\hline
\end{tabular}

In the following sections, only some representative GC analytical details are given, as it will take lots of space to provide complete GC analytical data of all the catalytic reactions tested.

\subsection{GC analytical details of a representative transesterification reaction product Benzyl acetate (BnA)}

The GC conditions employed such as inlet temp., column used, column temp., detector temp. etc for BnA are as tabulated under section $\mathbf{1 0 .}$ 


\section{A. Gas chromatograms of standard samples to draw the calibration plot for BnA:}

$0.071 \mathrm{ml}(0.5 \mathrm{mM})$ of $\mathrm{BnA}+75 \mu \mathrm{l}$ of 1,2,4-trimethylbenzene (124-TMB, internal standard) in $10 \mathrm{ml}$ of dichloromethane (DCM)

Area \% Report

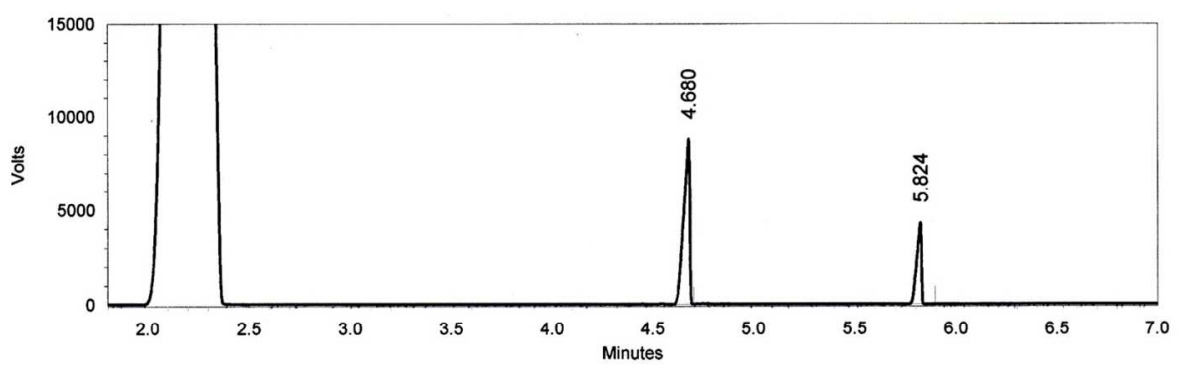

\begin{tabular}{|c|c|c|c|c|c|}
\hline $\begin{array}{l}\text { Front Signal } \\
\text { Results } \\
\text { Peak Number }\end{array}$ & Ret. Time & Area & Height & Concentration & $\begin{array}{c}\text { Compound } \\
\text { Name }\end{array}$ \\
\hline 1 & 4.680 & 139713608 & 67354253 & 72.9 & 124-TMB \\
\hline 2 & 5.824 & 51885961 & 32783205 & 27.1 & Benzyl acetate \\
\hline Totals & & 191599569 & 100137458 & 100.0 & \\
\hline
\end{tabular}

Conc: of BnA/conc: of 124-TMB $=0.37$

\section{$0.106 \mathrm{ml}(0.75 \mathrm{mM})$ of $\mathrm{BnA}+75 \mu \mathrm{l}$ of $124-\mathrm{TMB}$ in $10 \mathrm{ml}$ of $\mathrm{DCM}$}

Area \% Report

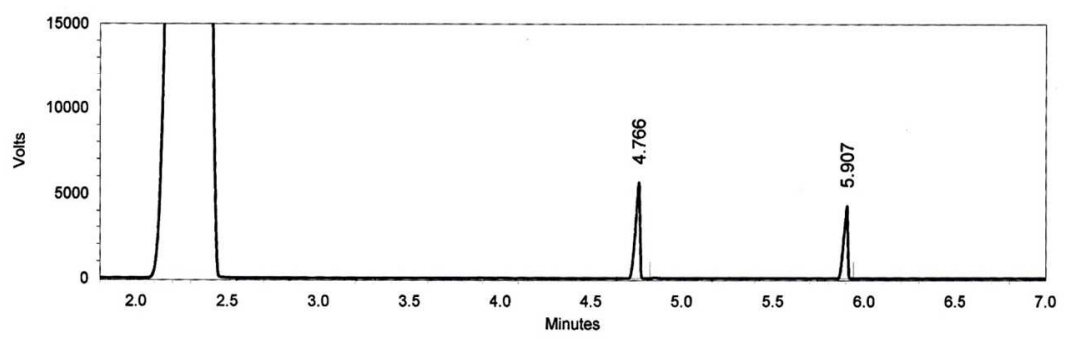

\begin{tabular}{|c|c|c|c|c|c|}
\hline $\begin{array}{l}\text { Front Signal } \\
\text { Results } \\
\text { Peak Number }\end{array}$ & Ret. Time & Area & Height & Concentration & $\begin{array}{c}\text { Compound } \\
\text { Name }\end{array}$ \\
\hline 1 & 4.766 & 72929547 & 43178983 & 58.6 & 124-TMB \\
\hline 2 & 5.907 & 51465116 & 32691704 & 41.4 & Benzyl acetate \\
\hline Totals & & & & & \\
\hline
\end{tabular}

Conc: of $\mathrm{BnA}$ / conc: of 124-TMB $=0.71$ 


\section{$0.141 \mathrm{ml}(1.0 \mathrm{mM})$ of $\mathrm{BnA}+75 \mu \mathrm{l}$ of $124-\mathrm{TMB}$ in $10 \mathrm{ml}$ of $\mathrm{DCM}$}

Area \% Report

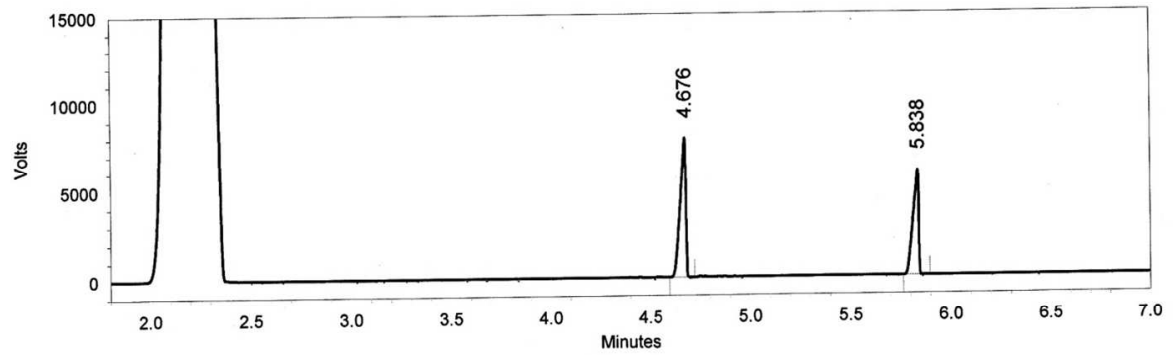

\begin{tabular}{|c|c|c|c|c|c|}
\hline $\begin{array}{l}\text { Front Signal } \\
\text { Results } \\
\text { Peak Number }\end{array}$ & Ret. Time & Area & Height & Concentration & $\begin{array}{c}\text { Compound } \\
\text { Name }\end{array}$ \\
\hline C & $\begin{array}{l}4.676 \\
5838\end{array}$ & 115460015 & 60324609 & $\begin{array}{l}56.7 \\
43.3\end{array}$ & $\begin{array}{l}\text { 124-TMB } \\
\text { Benzyl acetate }\end{array}$ \\
\hline Totals & & 203685475 & 105583529 & 100.0 & \\
\hline
\end{tabular}

Conc: of $\mathrm{BnA}$ / conc: of 124-TMB $=0.76$

\section{$0.177 \mathrm{ml}(1.25 \mathrm{mM})$ of $\mathrm{BnA}+75 \mu \mathrm{l}$ of $124-\mathrm{TMB}$ in $10 \mathrm{ml}$ of DCM}

\section{Area \% Report}

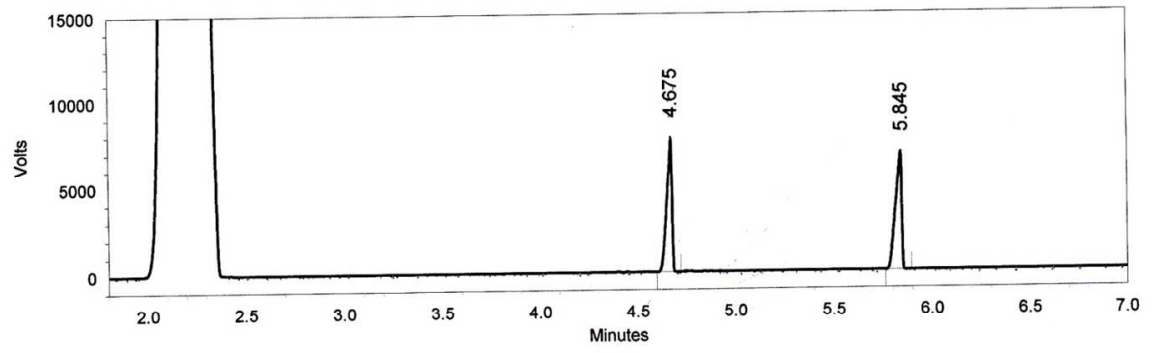

\begin{tabular}{|c|c|c|c|c|c|}
\hline $\begin{array}{l}\text { Front Signal } \\
\text { Results } \\
\text { Peak Number }\end{array}$ & Ret. Time & Area & Height & Concentration & $\begin{array}{l}\text { Compound } \\
\text { Name }\end{array}$ \\
\hline 1 & 4.675 & 111585927 & 59433416 & 49.9 & 124-TMB \\
\hline 2 & 5.845 & 112084955 & 52055178 & 50.1 & Benzyl acetate \\
\hline Totals & & 223670882 & 111488594 & 100.0 & \\
\hline
\end{tabular}

Conc: of BnA / conc: of 124-TMB $=1.0$ 
(B) Gas chromatograms of transesterification product of PA with benzyl alcohol in presence of various catalysts $4 \mathrm{~A}-4 \mathrm{D}$

Reaction product (unknown concentration of $\mathrm{BnA}$ ) $+75.0 \mu \mathrm{l}$ of $124-\mathrm{TMB}$ in $10 \mathrm{ml}$ of DCM

(i) With complex $\mathbf{4 A}$ as catalyst:

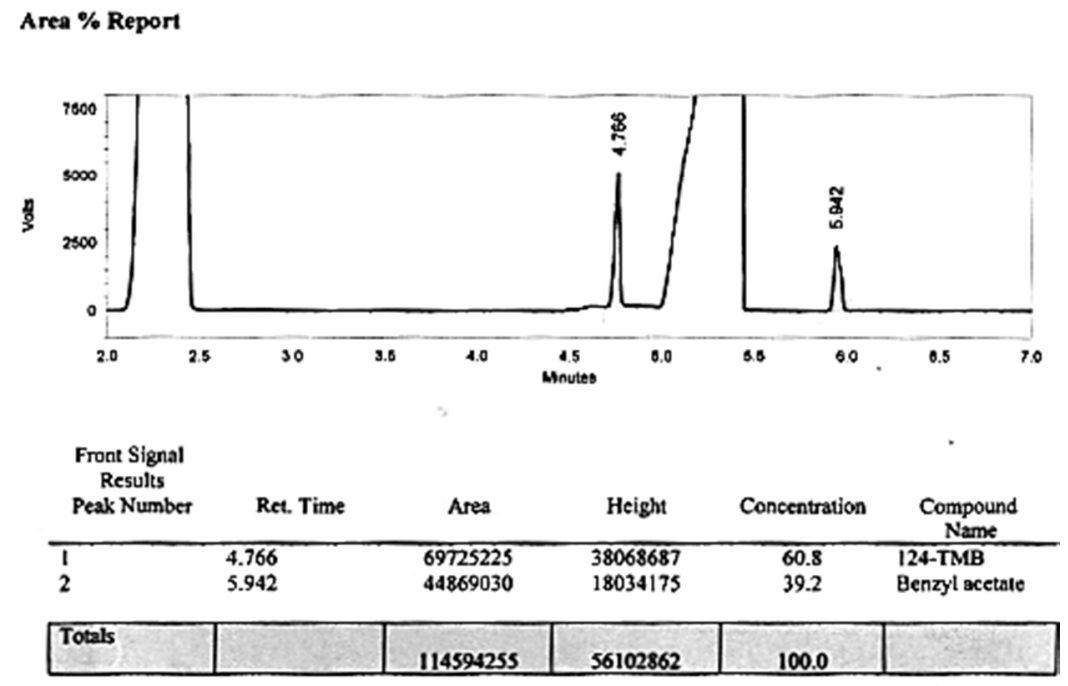

Conc: of BnA / conc. of 124-TMB $=0.64$

(ii) With complex 4B as catalyst:

Area \% Report

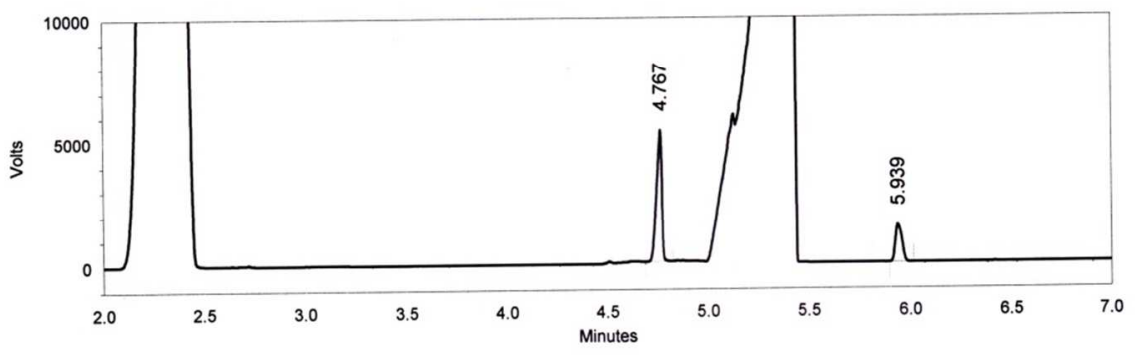

\begin{tabular}{|c|c|c|c|c|c|}
\hline $\begin{array}{l}\text { Front Signal } \\
\text { Results } \\
\text { Peak Number }\end{array}$ & Ret. Time & Area & Height & Concentration & $\begin{array}{c}\text { Compound } \\
\text { Name }\end{array}$ \\
\hline 1 & 4.767 & 74723234 & 40838263 & 74.6 & 124-TMB \\
\hline 2 & 5.939 & 25394754 & 11337249 & 25.4 & Benzyl acetate \\
\hline Totals & & 100117988 & 52175512 & 100.0 & \\
\hline
\end{tabular}

Conc: of BnA / conc: of 124-TMB $=0.34$ 
(iii) With complex $\mathbf{4 C}$ as catalyst:

\section{Area \% Report}

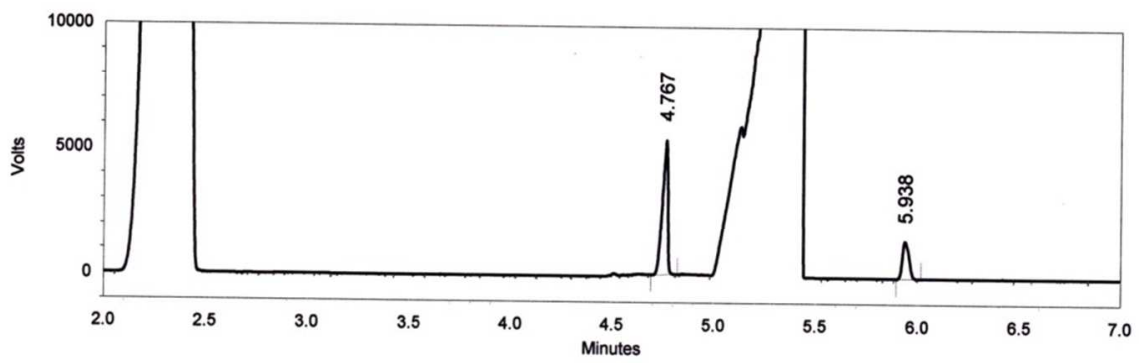

\begin{tabular}{|c|c|c|c|c|c|}
\hline $\begin{array}{l}\text { Front Signal } \\
\text { Results } \\
\text { Peak Number }\end{array}$ & Ret. Time & Area & Height & Concentration & $\begin{array}{c}\text { Compound } \\
\text { Name }\end{array}$ \\
\hline $\begin{array}{l}1 \\
2\end{array}$ & 4.767 & 75034817 & 40963520 & 75.5 & 124-TMB \\
\hline \multirow[t]{2}{*}{ Totals } & & & & & \\
\hline & & 99372860 & 52061405 & 100.0 & \\
\hline
\end{tabular}

Conc: of $\mathrm{BnA}$ / conc: of 124-TMB $=0.32$

(iv) With complex 4D as catalyst:

\section{Area \% Report}

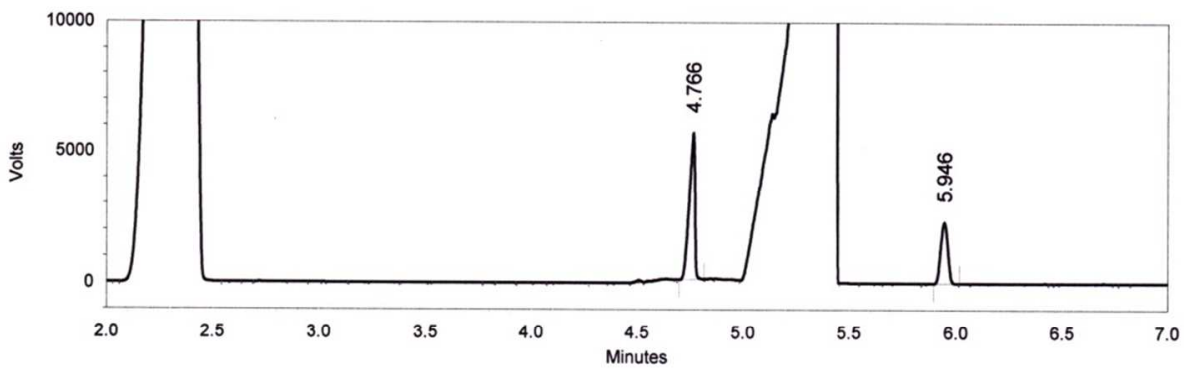

\begin{tabular}{lcccccc}
$\begin{array}{c}\text { Front Signal } \\
\text { Results } \\
\text { Peak Number }\end{array}$ & Ret. Time & Area & Height & Concentration & $\begin{array}{c}\text { Compound } \\
\text { Name }\end{array}$ \\
\hline 1 & 4.766 & 78984638 & 42764939 & 66.5 & $\begin{array}{l}\text { 124-TMB } \\
\text { Benzyl acetate }\end{array}$ \\
\hline & 5.946 & 39758488 & 17553552 & 33.5 & \\
\hline Totals & & 118743126 & 60318491 & 100.0 & \\
\hline
\end{tabular}

Conc: of BnA / conc: of 124-TMB $=0.50$ 


\section{Calibration plot for BnA}

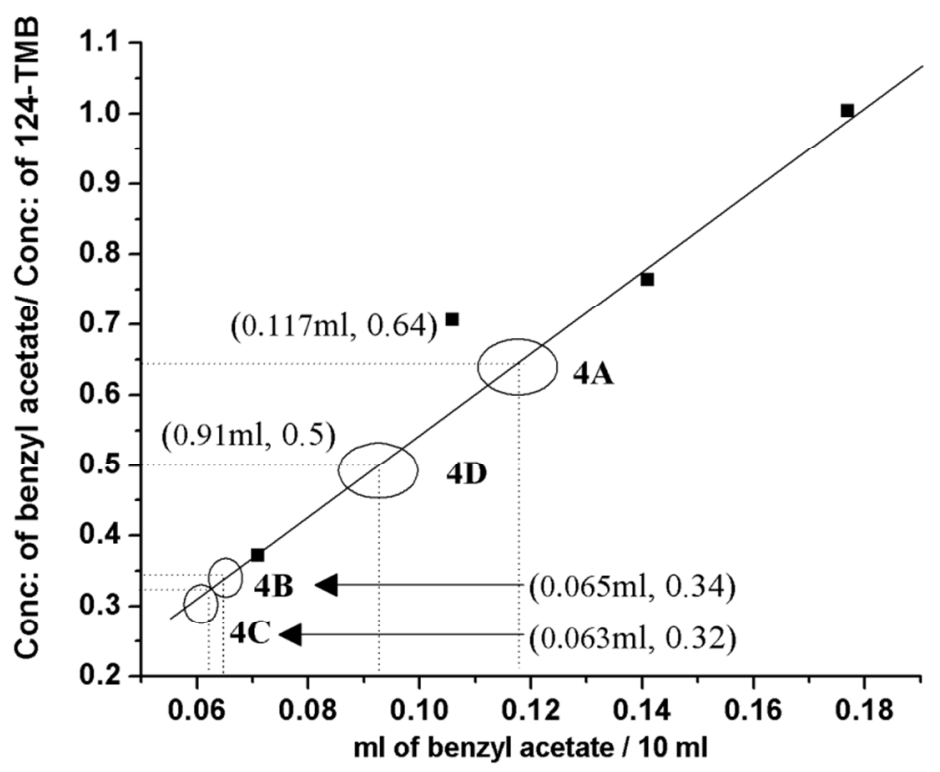

Figure S21. Calibration plot for BnA to determine the amount of product formed in various catalysis reactions.

From the calibration plot, the concentrations of $\mathrm{BnA}$ formed in the reaction of benzyl alcohol $(\mathrm{BnOH})$ with phenyl acetate catalyzed by complexes $\mathbf{4 A}, \mathbf{4 B}, \mathbf{4 C}$ and $\mathbf{4 D}$ were found to be 0.117 $\mathrm{ml}($ yield $=83 \%), 0.065 \mathrm{ml}($ yield $=46 \%), 0.063 \mathrm{ml}($ yield $=44 \%)$ and $0.091 \mathrm{ml}($ yield $=64 \%)$ respectively.

\subsection{GC conditions employed for the estimation of methyl acetate (MA)}

\begin{tabular}{ll}
\hline Condition & MA \\
\hline Inlet temperature & $300^{\circ} \mathrm{C}$ \\
Injecting volume & $1 \mu \mathrm{l}$ \\
Splitless flow & $40 \mathrm{ml} / \mathrm{min}$ \\
Column & $\mathrm{DB}-\mathrm{Wax}-5$ column $(30 \mathrm{~m} \times 530 \mu \mathrm{M} \times 1.0 \mu \mathrm{M})$ \\
Column 2 flow & $\mathrm{N}_{2}$ at $1 \mathrm{ml} / \min$ constant flow \\
Column temperature & $35^{\circ} \mathrm{C}$ for 1 min \\
& $20^{\circ} \mathrm{C} / \min$ to $215^{\circ} \mathrm{C}$ \\
Flame ionization detector (FID) & $300^{\circ} \mathrm{C}$ \\
\hline
\end{tabular}


(A). Gas chromatograms of standard samples to draw the calibration plot for MA

$0.0199 \mathrm{ml}(0.25 \mathrm{mM})$ of $\mathrm{MA}+75 \mu \mathrm{l}$ of $124-\mathrm{TMB}$ in $10 \mathrm{ml}$ of DCM

Area \% Report
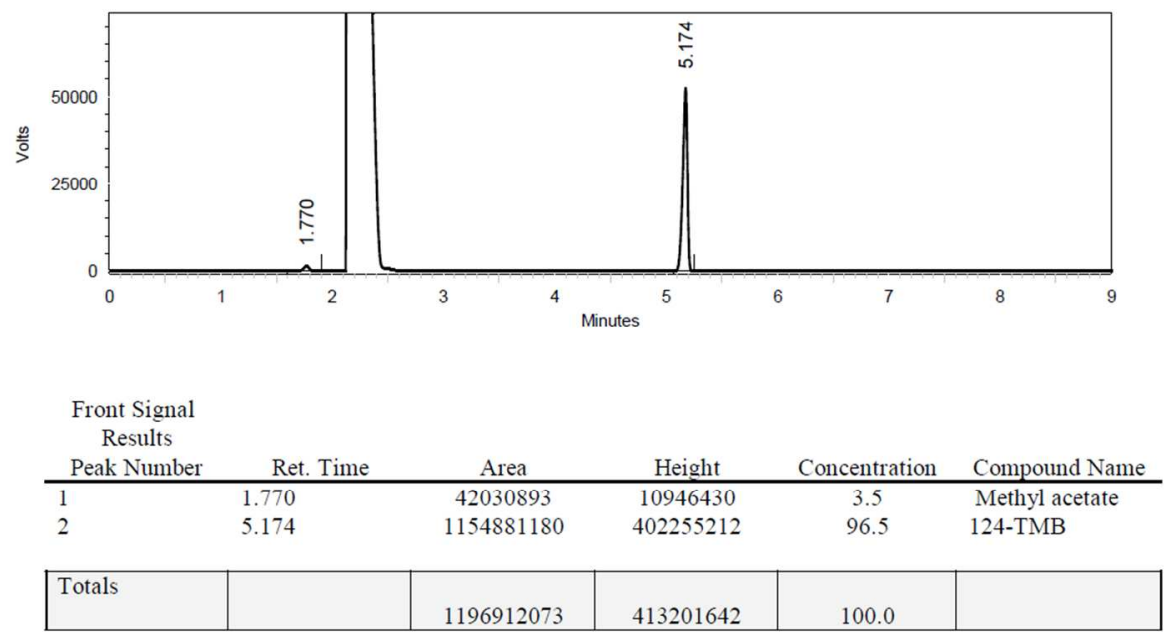

Conc: of MA / conc: of $124-\mathrm{TMB}=0.036$

$0.039 \mathrm{ml}(0.50 \mathrm{mM})$ of MA $+75 \mu \mathrm{l}$ of $124-\mathrm{TMB}$ in $10 \mathrm{ml}$ of DCM

Area \% Report

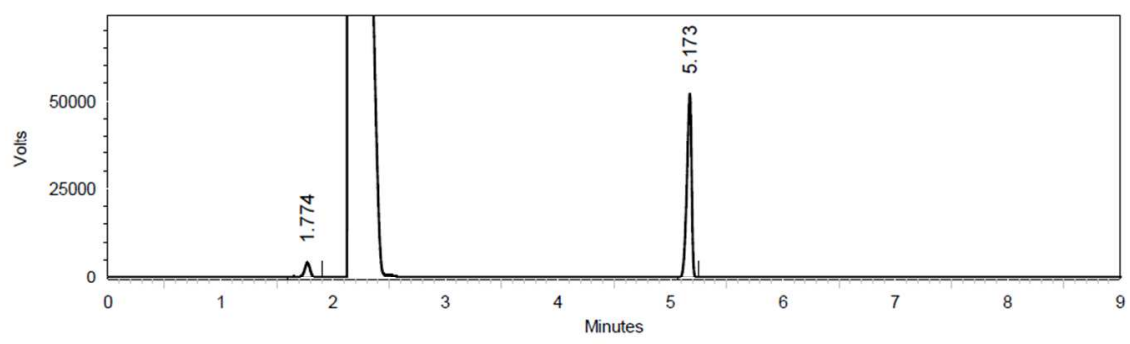

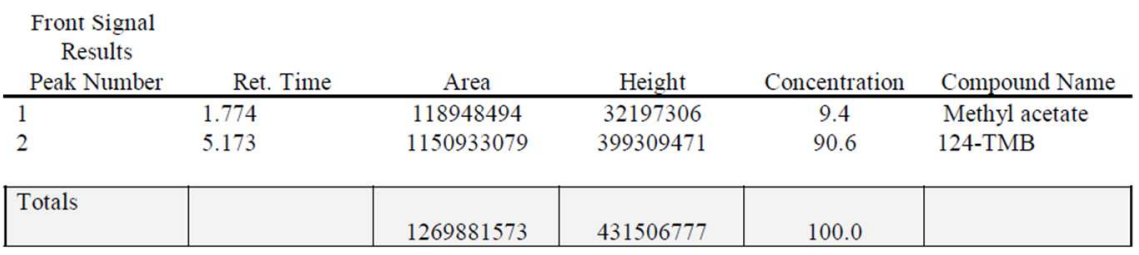

Conc: of MA / conc: of 124-TMB $=0.103$ 
$0.059 \mathrm{ml}(0.75 \mathrm{mM})$ of $\mathrm{MA}+75 \mu \mathrm{l}$ of $124-\mathrm{TMB}$ in $10 \mathrm{ml}$ of $\mathrm{DCM}$

Area \% Report

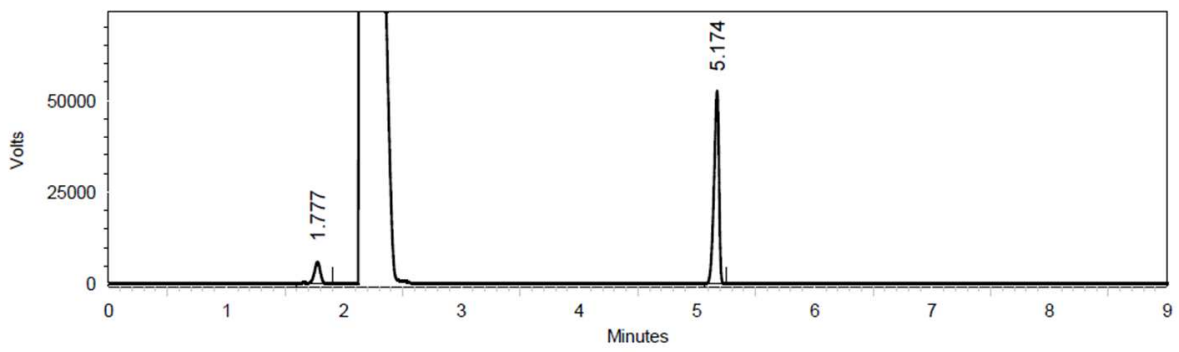

\begin{tabular}{|c|c|c|c|c|c|}
\hline $\begin{array}{l}\text { Front Signal } \\
\text { Results }\end{array}$ & & & & & \\
\hline Peak Number & Ret. Time & Area & Height & Concentration & Compound Name \\
\hline 1 & 1.777 & 175597523 & 47536954 & 13.0 & Methyl acetate \\
\hline 2 & 5.174 & 1173810875 & 403545346 & 87.0 & 124-TMB \\
\hline \multirow[t]{2}{*}{ Totals } & & & & & \\
\hline & & 1349408398 & 451082300 & 100.0 & \\
\hline
\end{tabular}

Conc: of MA / conc: of 124-TMB = 0.149

\section{$0.079 \mathrm{ml}(1.0 \mathrm{mM})$ of MA $+75 \mu \mathrm{l}$ of $124-\mathrm{TMB}$ in $10 \mathrm{ml}$ of DCM}

Area \% Report

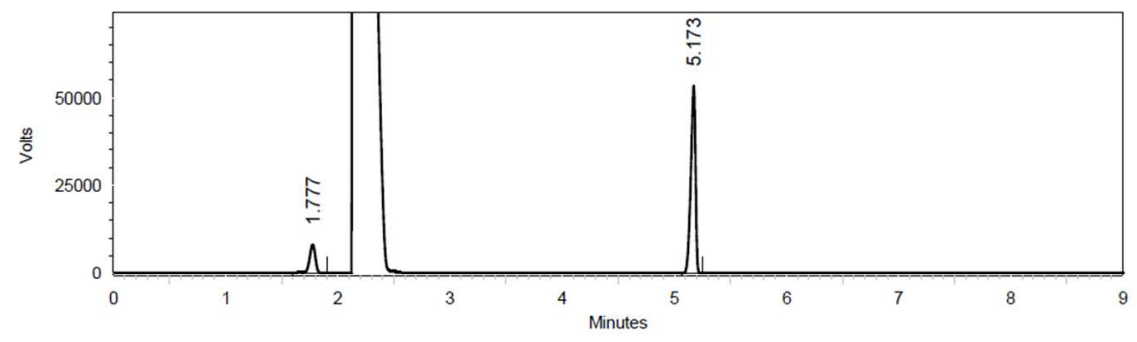

\begin{tabular}{llcccc}
$\begin{array}{c}\text { Front Signal } \\
\text { Results } \\
\text { Peak Number }\end{array}$ & Ret. Time & Area & Height & Concentration & Compound Name \\
\hline 1 & 1.777 & 237487669 & 62877272 & 16.7 & Methyl acetate \\
2 & 5.173 & 1181237325 & 409924300 & 83.3 & 124-TMB \\
\hline Totals & & 1418724994 & 472801572 & 100.0 & \\
\hline
\end{tabular}

Conc: of MA / conc: of 124-TMB $=0.20$ 
$0.0119 \mathrm{ml}(1.50 \mathrm{mM})$ of $\mathrm{MA}+75 \mu \mathrm{l}$ of $124-\mathrm{TMB}$ in $10 \mathrm{ml}$ of $\mathrm{DCM}$

Area \% Report
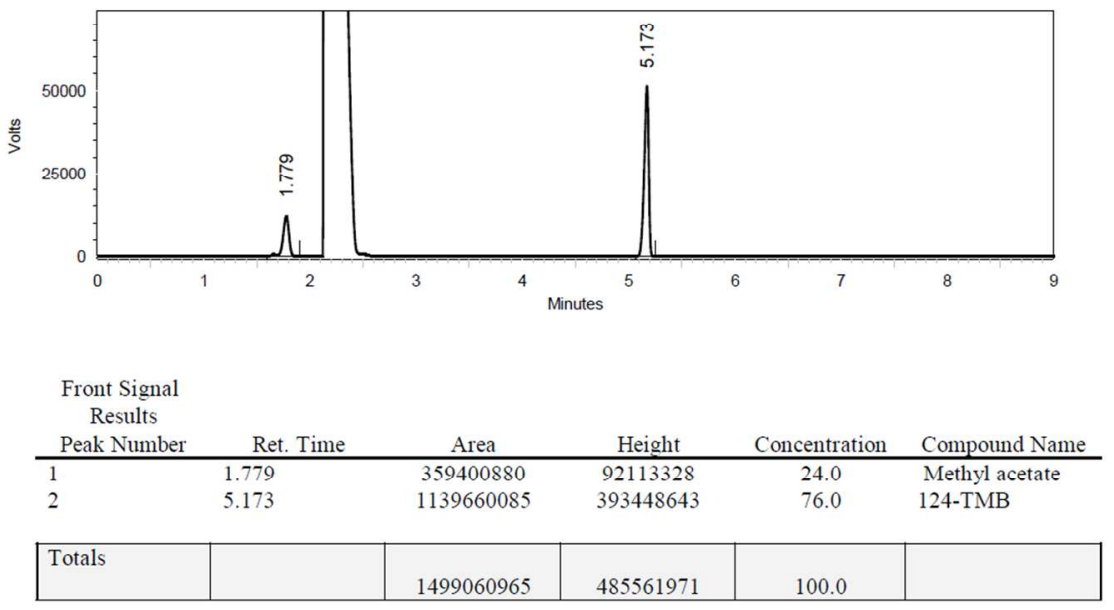

Conc: of MA / conc: of 124-TMB $=0.315$

$0.0159 \mathrm{ml}(2.0 \mathrm{mM})$ of MA $+75 \mu \mathrm{l}$ of $124-\mathrm{TMB}$ in $10 \mathrm{ml}$ of $\mathrm{DCM}$

Area \% Report

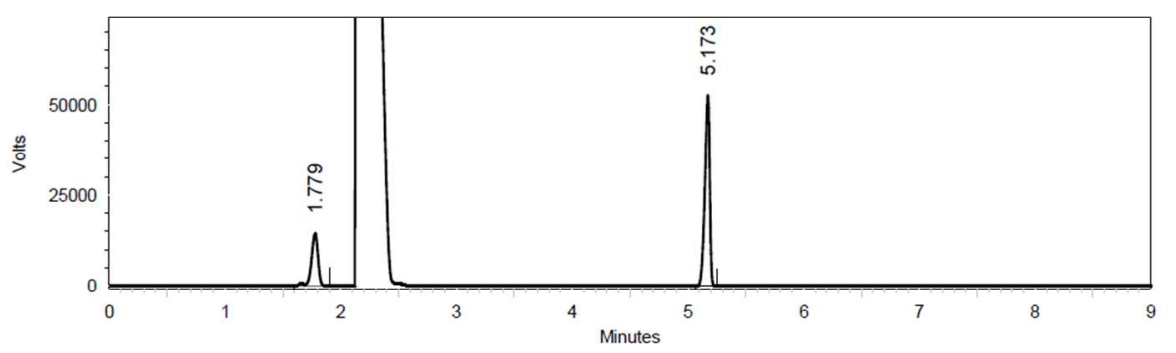

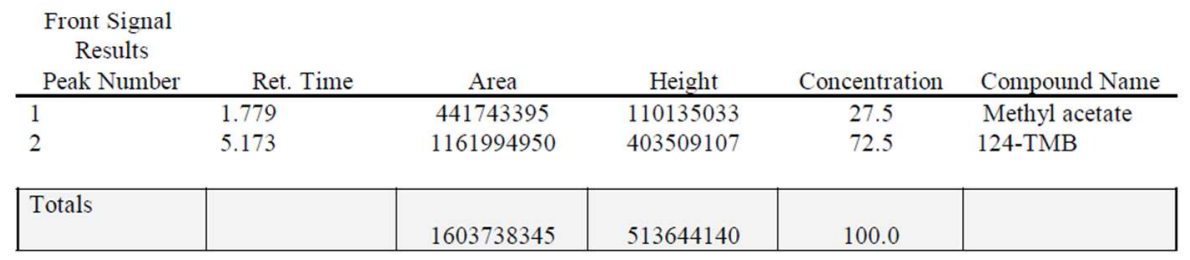

Conc: of MA / conc: of 124-TMB $=0.379$ 


\section{(B). Gas chromatograms of the transesterification products of phenyl acetate with $\mathrm{MeOH}$}

Reaction products containing unknown concentration of MA $+75.0 \mu 1$ of $124-\mathrm{TMB}$ in 10 $\mathrm{ml}$ of DCM

(i) With complex $\mathbf{4 A}$ as catalyst:

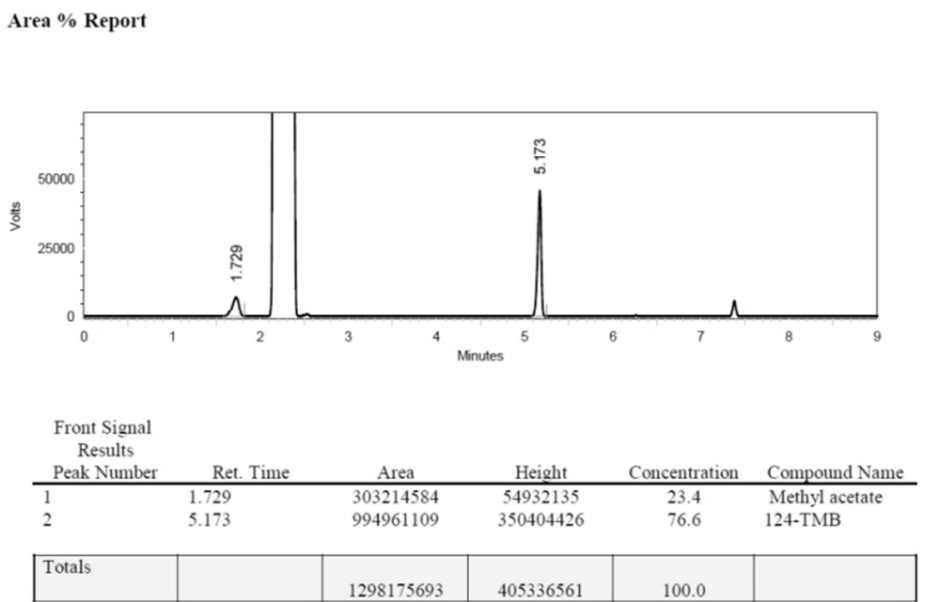

Conc: of MA / conc: of 124-TMB $=0.305$

(ii) With complex $\mathbf{4 B}$ as catalyst:

Area \% Report

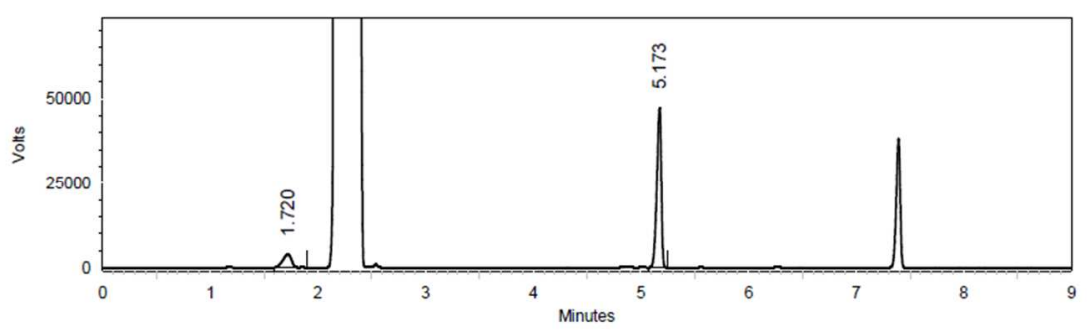

\begin{tabular}{|c|c|c|c|c|c|}
\hline $\begin{array}{l}\text { Front Signal } \\
\text { Results } \\
\text { Peak Number }\end{array}$ & Ret. Time & Area & Height & Concentration & Compound Name \\
\hline 1 & 1.720 & 165976524 & 29140573 & 13.8 & Methyl acetate \\
\hline 2 & 5.173 & 1033052429 & 362028164 & 86.2 & 124-TMB \\
\hline Totals & & 1199028953 & 391168737 & 100.0 & \\
\hline
\end{tabular}

Conc: of MA / conc: of $124-\mathrm{TMB}=0.160$ 
(iii) With complex $\mathbf{4 C}$ as catalyst:

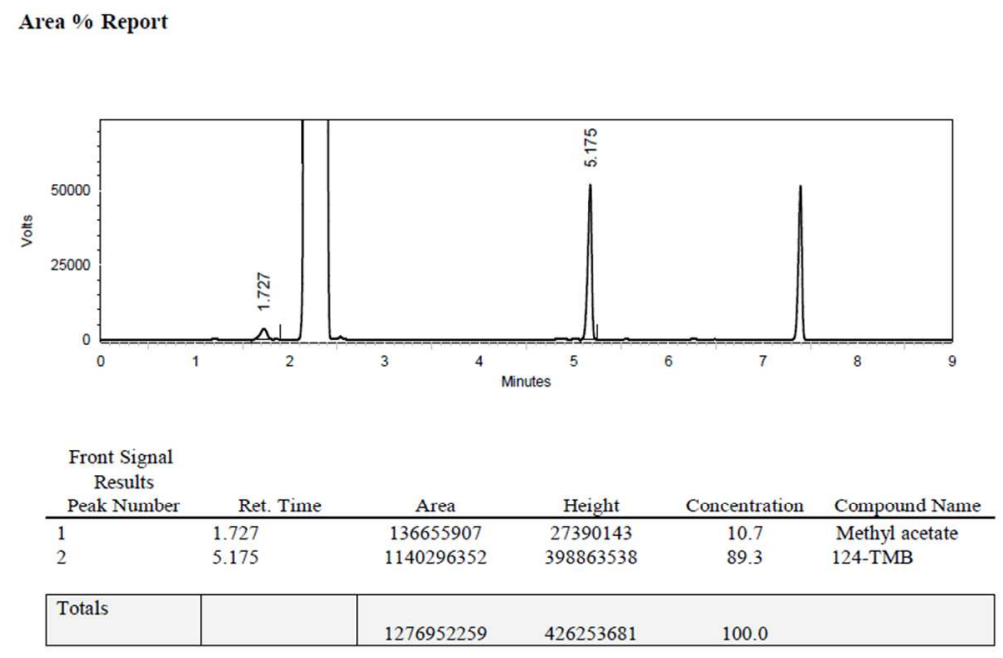

Conc: of MA / conc: of 124-TMB $=0.119$

(iv) With complex 4D as catalyst:

Area \% Report
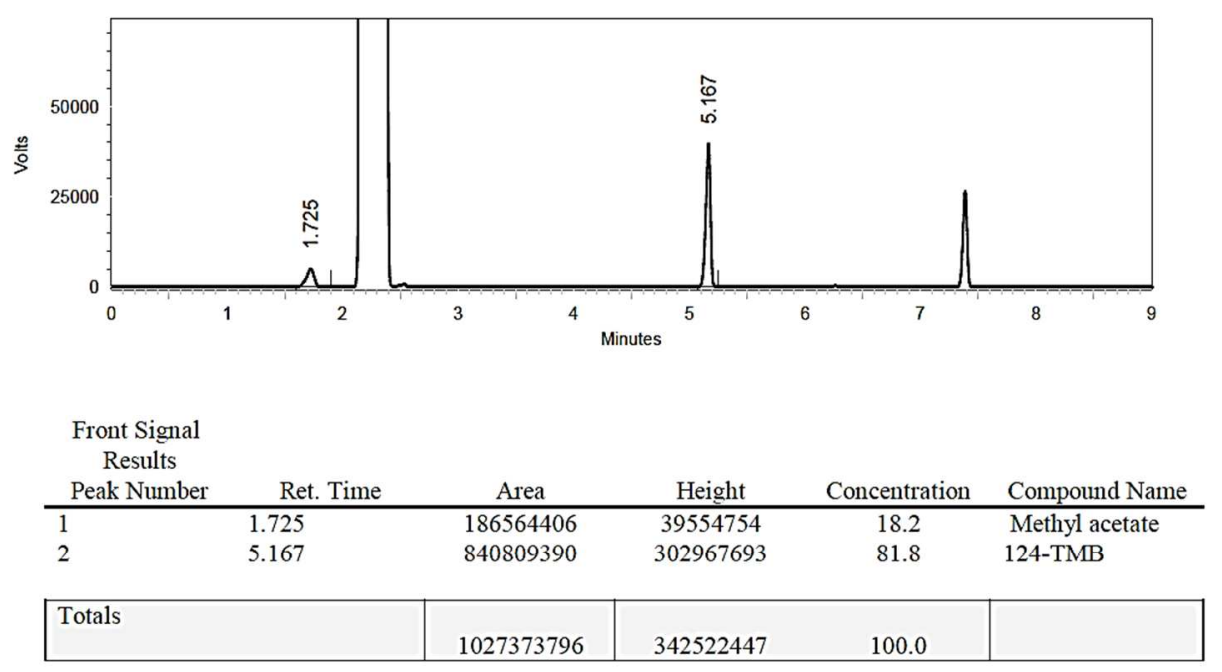

Conc: of MA / conc: of 124-TMB $=0.222$ 


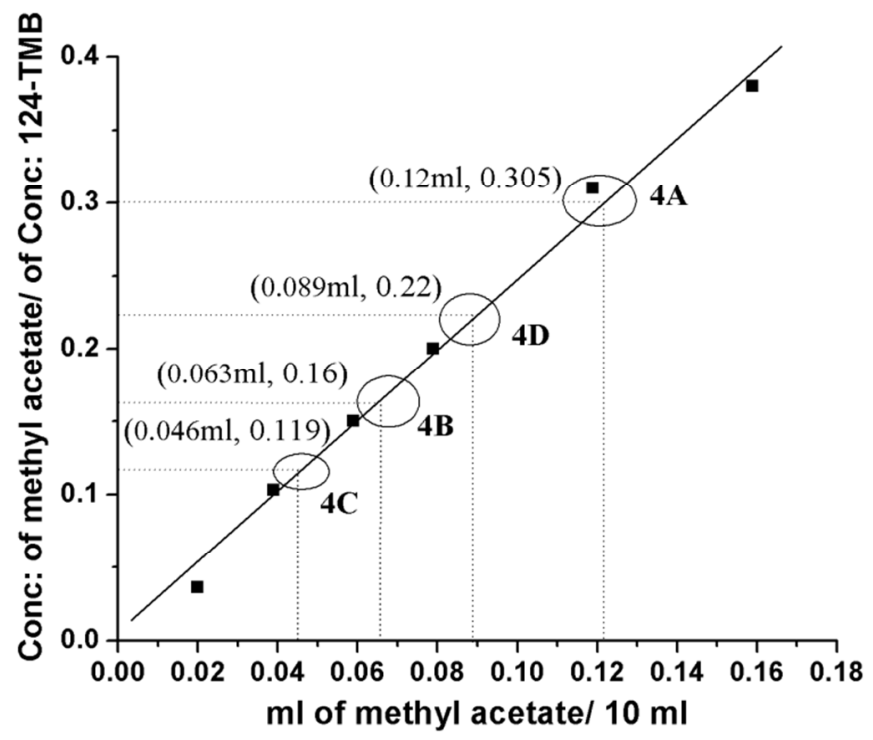

Figure S22. Calibration plot for methyl acetate to determine the amount of product formed in various catalysis reactions

From the calibration plot, the concentration of MA formed in the reaction of methanol with $1.5 \mathrm{mM}$ phenyl acetate catalyzed by complexes $\mathbf{4 A}, \mathbf{4 B}, \mathbf{4 C}$ and $4 \mathrm{D}$ were found to be $0.12 \mathrm{ml}$ $($ yield $=100 \%), 0.063 \mathrm{ml}($ yield $=52 \%), 0.046 \mathrm{ml}($ yield $=38 \%)$ and $0.089 \mathrm{ml}($ yield $=74 \%)$ respectively.

\section{(C) Gas chromatograms of the transesterification products of triacetin in $\mathrm{MeOH}$}

Reaction products containing unknown concentration of MA $+75.0 \mu 1$ of $124-\mathrm{TMB}$ in 10 $\mathrm{ml}$ of DCM

(i) With complex $\mathbf{4 A}$ as catalyst:

Area \% Report
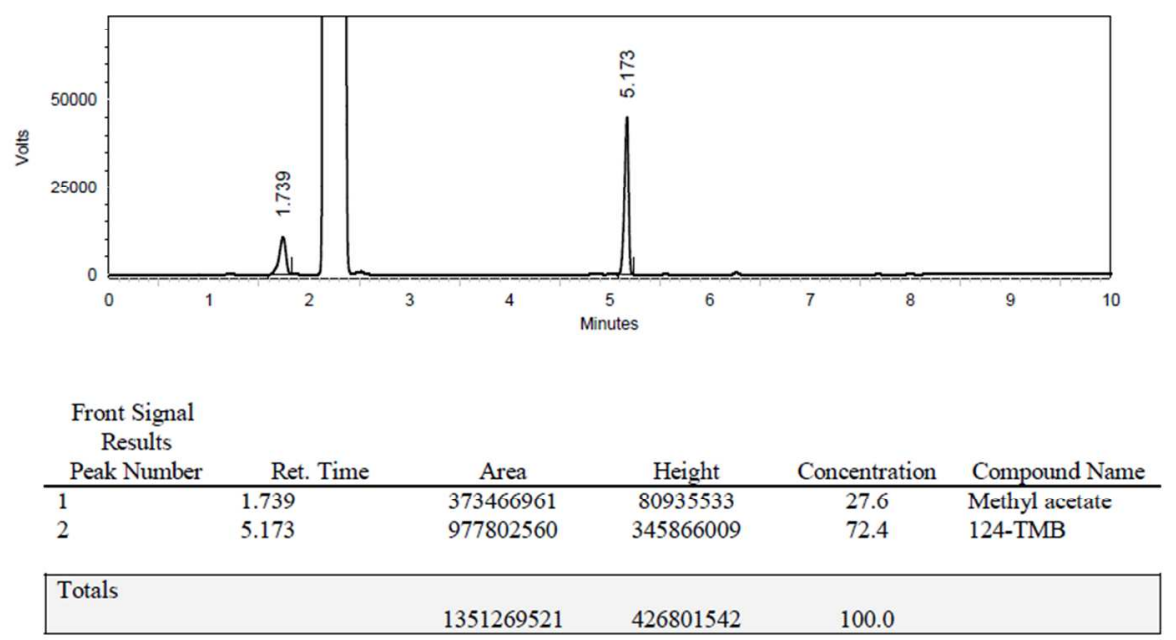

Conc: of MA / conc: of 124-TMB $=0.38$ 
(ii) With complex 4B as catalyst:

Area \% Report
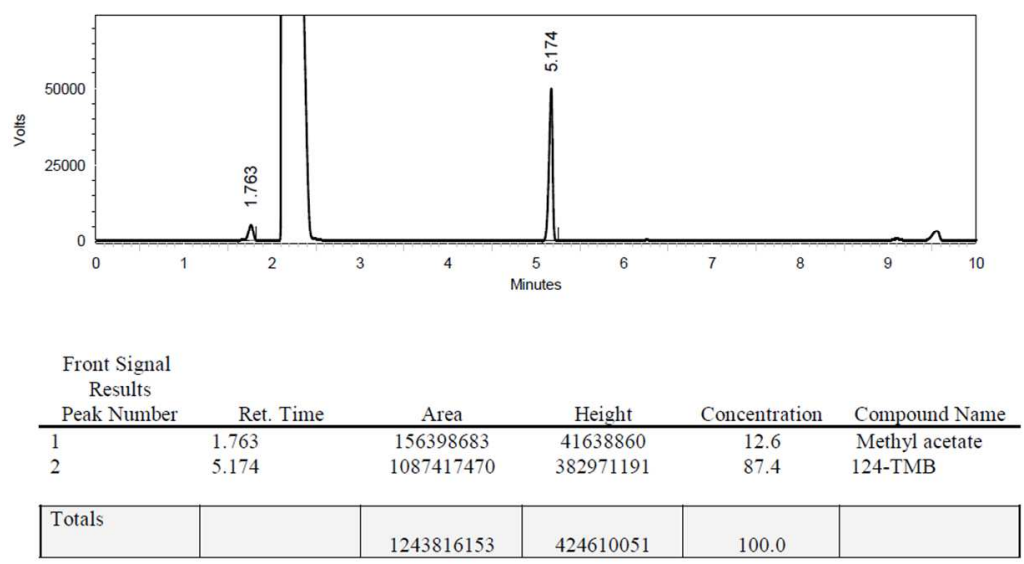

Conc: of MA / conc: of 124-TMB = 0.144

(iii) With complex 4C as catalyst:

Area \% Report
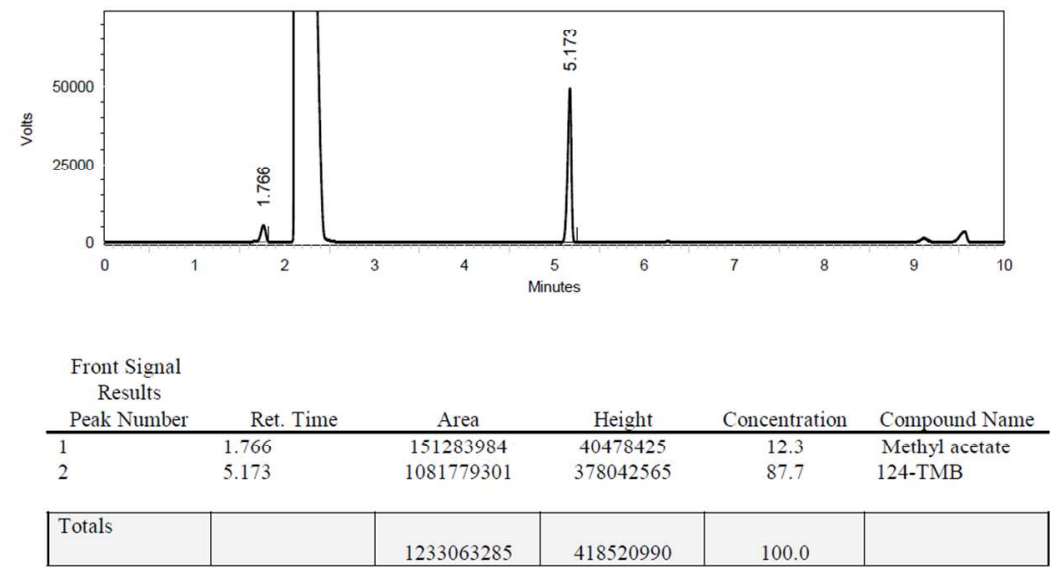

Conc: of MA / conc: of 124-TMB $=0.140$ 
(iv) With complex 4D as catalyst:

Area \% Report
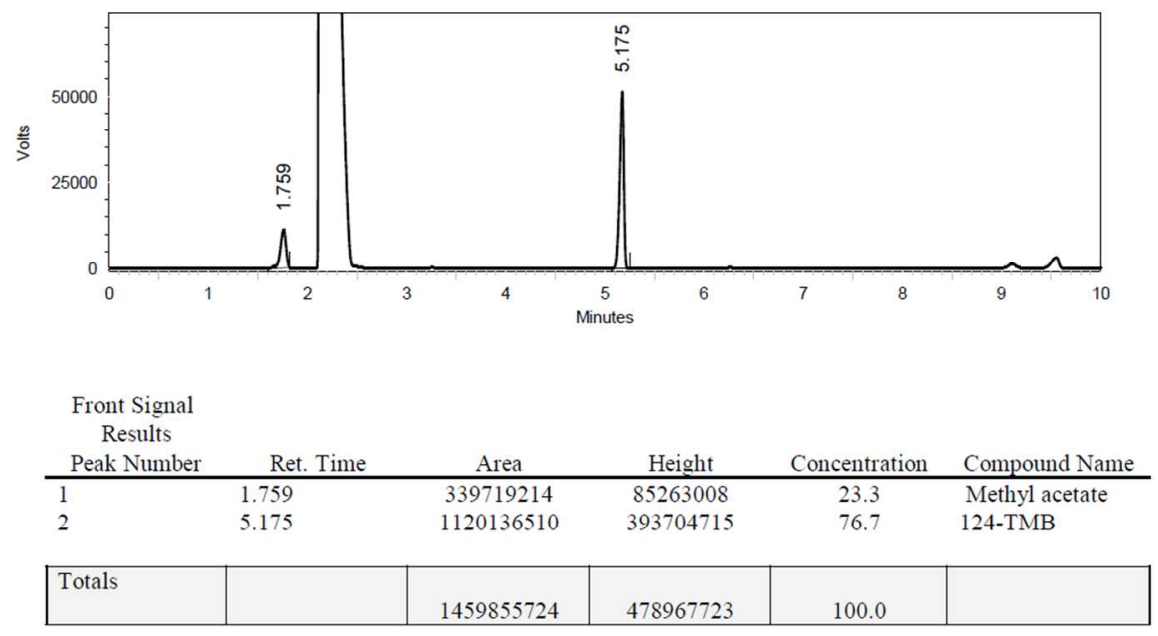

Conc: of MA / conc: of 124-TMB $=0.303$

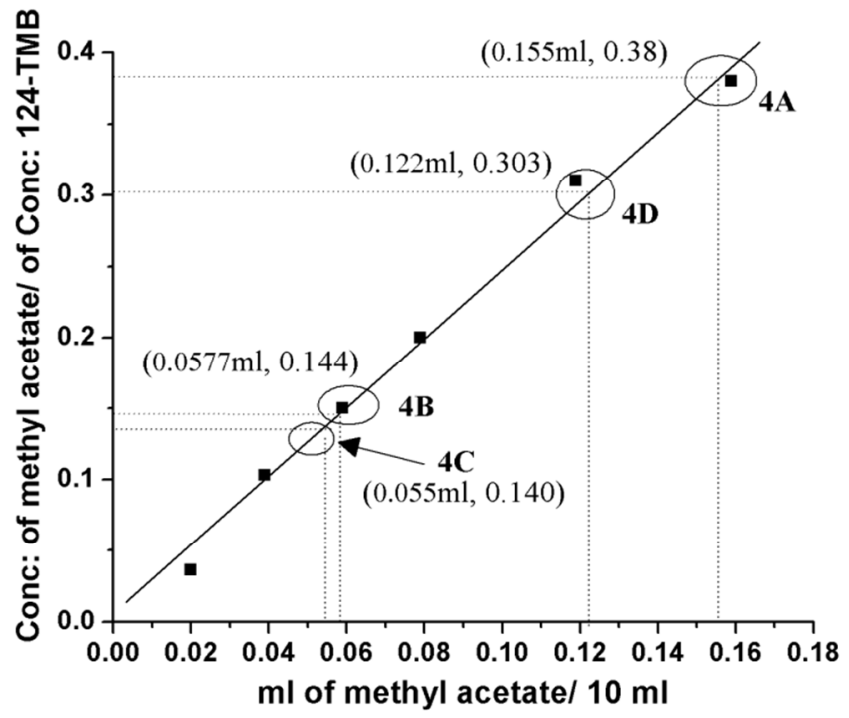

From the calibration plot (Figure S22), the concentration of MA formed in the reaction of methanol with $0.65 \mathrm{mM}$ triacetin catalyzed by complexes $\mathbf{4 A}, \mathbf{4 B}, \mathbf{4 C}$ and $4 \mathrm{D}$ were found to be $0.155 \mathrm{ml}(1.94 \mathrm{mM}$, yield $=99 \%), 0.0577 \mathrm{ml}(0.72 \mathrm{mM}$, yield $=37.0 \%), 0.055 \mathrm{ml}(0.69 \mathrm{mM}$, yield $=35 \%)$ and $0.122 \mathrm{ml}(1.53 \mathrm{mM}$, yield $=78 \%)$ respectively. 
10.3 GC conditions employed for the determination of FAME (methyl oleate (MO) and methyl linoleate (ML)\} content in the transesterification products of canola oil

GC Agilent 7890A series, split/ splitless inlet

\begin{tabular}{ll}
\hline Inlet temperature & $250^{\circ} \mathrm{C}$ \\
Injecting volume & $1 \mu \mathrm{l}$ \\
Splitless flow & $40 \mathrm{ml} / \mathrm{min}$ \\
Column & $\mathrm{HP}-5$ column $(5 \%$ phenyl methyl siloxan, $30 \mathrm{~m} \times 320 \mu \mathrm{M} \times 0.25 \mu \mathrm{M})$ \\
Column 2 flow & $\mathrm{N}_{2}$ at $3 \mathrm{ml} / \mathrm{min}$ constant flow \\
Column temperature & $80^{\circ} \mathrm{C}$ for $1 \mathrm{~min}$ \\
& $15^{\circ} \mathrm{C} / \mathrm{min}$ to $200^{\circ} \mathrm{C}$ hold for $5 \mathrm{~min}$ \\
& $10^{\circ} \mathrm{C} / \mathrm{min}$ to $240^{\circ} \mathrm{C}$ hold for $4 \mathrm{~min}$ \\
Flame ionization detector (FID) & $300^{\circ} \mathrm{C}$ \\
\hline
\end{tabular}

(A). Gas chromatograms of standard samples of FAME to draw the calibration plot

$8.4 \mu \mathrm{l}$ of $\mathrm{MO}+8.2 \mu \mathrm{l}$ of $\mathrm{ML}+7.5 \mu \mathrm{l}$ of $124-\mathrm{TMB}$ in $1 \mathrm{ml}$ of $\mathrm{DCM}$

Area \% Report

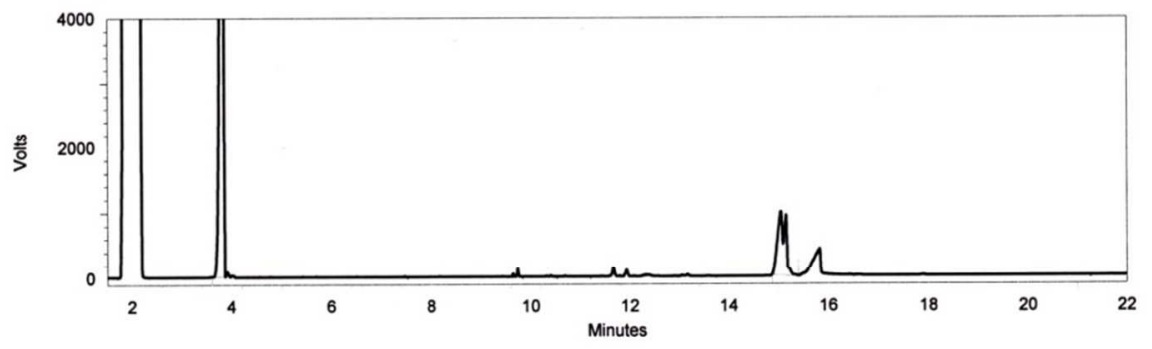

\begin{tabular}{llcccl}
$\begin{array}{c}\text { Front Signal } \\
\text { Results } \\
\text { Peak Number }\end{array}$ & \multicolumn{1}{c}{ Ret. Time } & \multicolumn{1}{c}{ Area } & Height & Concentration & Compound Name \\
\hline 1 & 3.851 & 442728435 & 104539748 & 84.2 & 124-TMB \\
2 & 15.045 & 83377248 & 7482100 & 15.8 & FAME(ML+MO) \\
\hline Totals & & 526105683 & 112021848 & 100.0 & \\
\hline
\end{tabular}

Conc: of FAME / conc: of 124-TMB $=0.187$ 
$16.8 \mu \mathrm{l}$ of $\mathrm{MO}+16.5 \mu \mathrm{l}$ of $\mathrm{ML}$ of $+7.5 \mu \mathrm{l}$ of $124-\mathrm{TMB}$ in $1 \mathrm{ml}$ of $\mathrm{DCM}$

Area \% Report

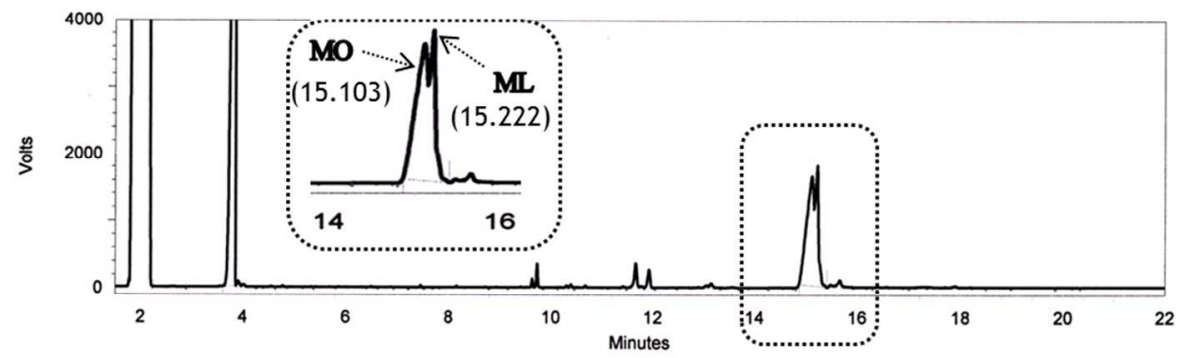

\begin{tabular}{|c|c|c|c|c|c|}
\hline $\begin{array}{l}\text { Front Signal } \\
\text { Results } \\
\text { Peak Number }\end{array}$ & Ret. Time & Area & Height & Concentration & Compound Name \\
\hline 1 & 3.847 & 508231895 & 110956955 & 73.3 & 124-TMB \\
\hline 2 & 15.117 & 185578335 & 12434118 & 26.7 & FAME $(M L+M O)$ \\
\hline Totals & & 693810230 & 123391073 & 100.0 & \\
\hline
\end{tabular}

Conc: of FAME / conc: of 124-TMB $=0.364$

$25.0 \mu \mathrm{MO}+24.8 \mu \mathrm{l} \mathrm{ML}+7.5 \mu \mathrm{l}$ of $124-\mathrm{TMB}$ in $1 \mathrm{ml}$ of $\mathrm{DCM}$

Area \% Report

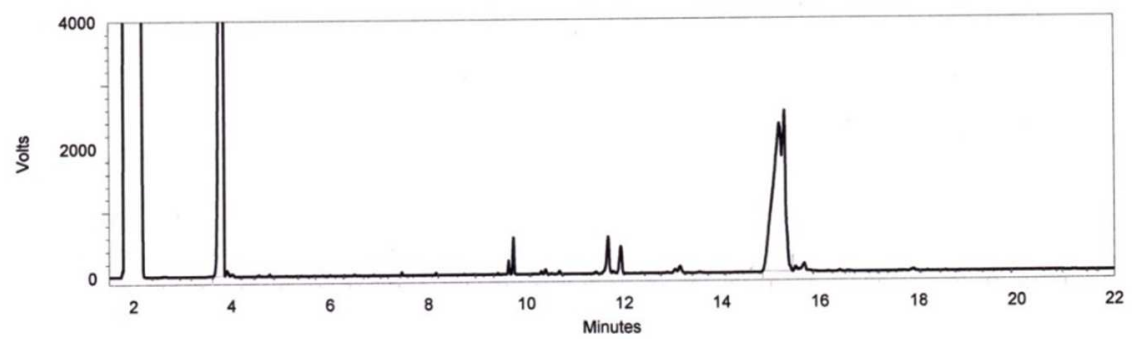

\begin{tabular}{|c|c|c|c|c|c|}
\hline $\begin{array}{l}\text { Front Signal } \\
\text { Results } \\
\text { Peak Number }\end{array}$ & Ret. Time & Area & Height & Concentration & Compound Name \\
\hline 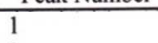 & 3.846 & 519427128 & 111380411 & 63.0 & 124-TMB \\
\hline 2 & 15.177 & 305237116 & 17664510 & 37.0 & $\mathrm{FAME}(\mathrm{ML}+\mathrm{MO})$ \\
\hline Totals & & 824664244 & 129044921 & 100.0 & \\
\hline
\end{tabular}

Conc: of FAME / conc: of 124-TMB $=0.587$ 


\section{$33.6 \mu \mathrm{l} \mathrm{MO}+33.1 \mu \mathrm{l} \mathrm{ML}+7.5 \mu \mathrm{l}$ of $124-\mathrm{TMB}$ in $1 \mathrm{ml}$ of $\mathrm{DCM}$}

Area \% Report

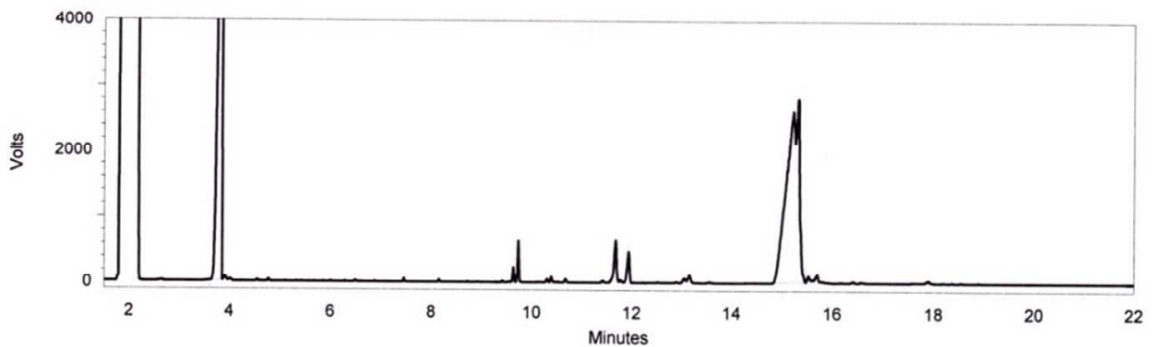

\begin{tabular}{llccc|c|}
$\begin{array}{c}\text { Front Signal } \\
\text { Results } \\
\text { Peak Number }\end{array}$ & \multicolumn{1}{c}{ Ret. Time } & Area & Height & Concentration & Compound Name \\
\hline 1 & 3.842 & 462173866 & 101011765 & 56.1 & 124-TMB \\
2 & 15.220 & 361577993 & 19992188 & 43.9 & FAME(ML+MO) \\
\hline Totals & & 823751859 & 121003953 & 100.0 & \\
\hline
\end{tabular}

Conc: of FAME / conc: of 124-TMB $=0.782$

$50.5 \mu \mathrm{l} \mathrm{MO}+50.5 \mu \mathrm{l} \mathrm{ML}+7.5 \mu \mathrm{l}$ of $124-\mathrm{TMB}$ in $1 \mathrm{ml}$ of DCM

Area \% Report

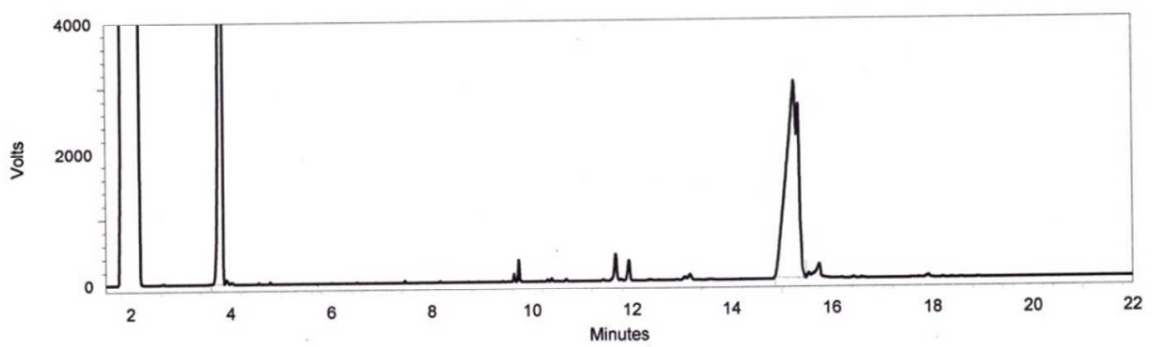

\begin{tabular}{llcccc|}
$\begin{array}{c}\text { Front Signal } \\
\text { Results } \\
\text { Peak Number }\end{array}$ & \multicolumn{1}{c}{ Ret. Time } & \multicolumn{1}{c}{ Area } & Height & Concentration & Compound Name \\
\hline 1 & 3.848 & 391702032 & 94358517 & 50.6 & 124-TMB \\
2 & 15.252 & 382206236 & 23017499 & 49.4 & FAME(ML+MO) \\
\hline Totals & & 773908268 & 117376016 & 100.0 & \\
\hline
\end{tabular}

Conc: of FAME / conc: of 124-TMB $=0.976$ 


\section{(B). Gas chromatogram of the transesterification products of canola oil}

Reaction product containing unknown concentration of FAME (MO and ML) obtained from $50.0 \mu \mathrm{l}$ of canola oil $+7.5 \mu 1$ of $124-\mathrm{TMB}$ in $1 \mathrm{ml}$ of $\mathrm{DCM}$.

(i) Reaction product without using any catalyst:

Area \% Report

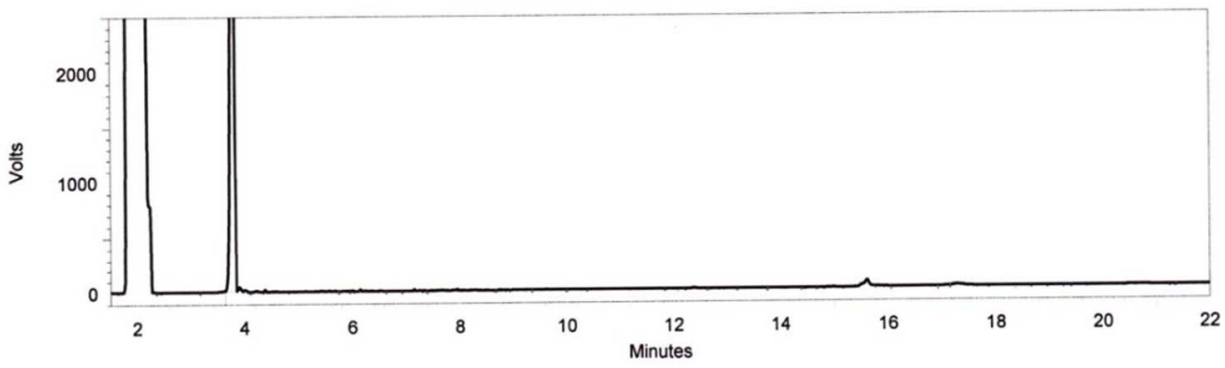

\begin{tabular}{lccc|c|c|}
$\begin{array}{l}\text { Front Signal } \\
\begin{array}{c}\text { Results } \\
\text { Peak Number }\end{array}\end{array}$ & Ret. Time & Area & Height & Concentration & Compound Name \\
\hline 1 & 3.828 & 266841328 & 62241813 & 100.0 & 124 -TMB \\
\hline Totals & & 266841328 & 62241813 & 100.0 & \\
\hline
\end{tabular}

(ii) Using complex $\mathbf{4 A}$ as catalyst:

Area \% Report

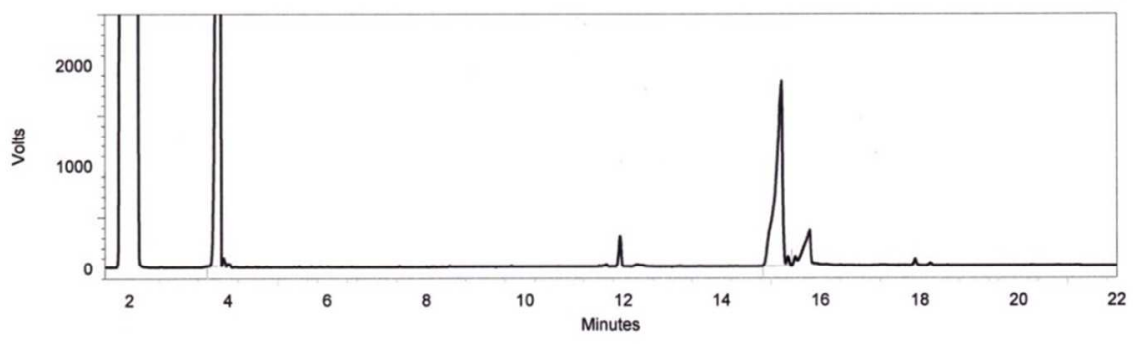

\begin{tabular}{llcccc}
$\begin{array}{c}\text { Front Signal } \\
\text { Results } \\
\text { Peak Number }\end{array}$ & \multicolumn{1}{c}{ Ret. Time } & Area & Height & Concentration & Compound Name \\
\hline 1 & 3.851 & 477946507 & 109589950 & 78.0 & 124-TMB \\
2 & 15.206 & 134652294 & 13649300 & 22.0 & FAME(ML+MO) \\
\hline Totals & & 612598801 & 123239250 & 100.0 & \\
\hline
\end{tabular}

Conc: of FAME / conc: of 124-TMB $=0.282$ 
(iii) Using complex 4B as catalyst:

Area \% Report

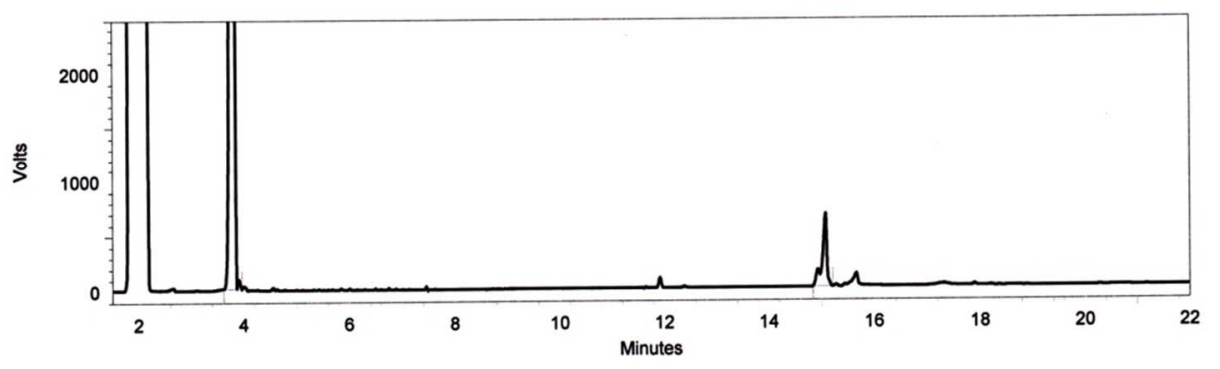

\begin{tabular}{|c|c|c|c|c|c|}
\hline $\begin{array}{l}\text { Front Signal } \\
\text { Results } \\
\text { Peak Number } \\
\end{array}$ & Ret. Time & Area & Height & Concentration & Compound Name \\
\hline 1 & 3.849 & 532030321 & 116525278 & 94.5 & 124-TMB \\
\hline 2 & 15.072 & 30951310 & 4986000 & 5.5 & FAME(ML+MO) \\
\hline Totals & & 562981631 & 121511278 & 100.0 & \\
\hline
\end{tabular}

Conc: of FAME / conc: of 124-TMB $=0.058$

(iv) Using complex $\mathbf{4 C}$ as catalyst:

Area \% Report

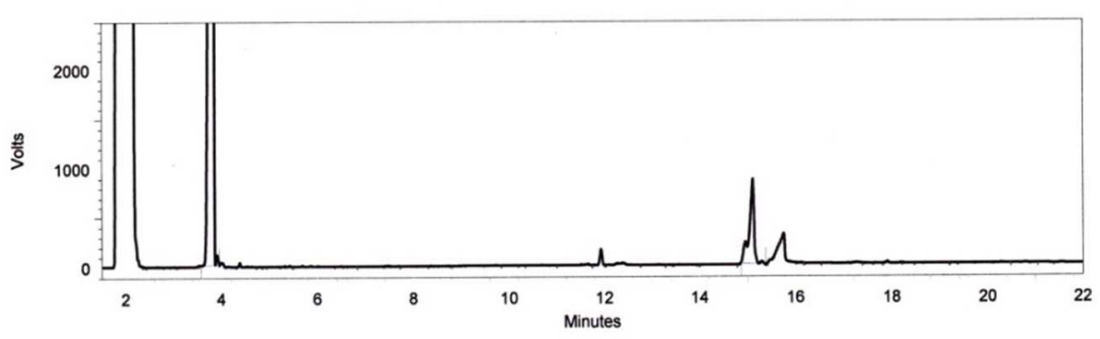

\begin{tabular}{llcccc|}
$\begin{array}{c}\text { Front Signal } \\
\text { Results } \\
\text { Peak Number }\end{array}$ & \multicolumn{1}{c}{ Ret. Time } & \multicolumn{1}{c}{ Area } & Height & Concentration & Compound Name \\
\hline 1 & 3.856 & 623021193 & 129193949 & 93.3 & $\begin{array}{l}124-\mathrm{TMB} \\
2\end{array}$ \\
\hline & 15.106 & 44961038 & 6524772 & 6.7 & FAME(ML+MO) \\
\hline Totals & & 667982231 & 135718721 & 100.0 & \\
\hline
\end{tabular}

Conc: of FAME / conc: of 124-TMB $=0.071$ 
(v) Using complex 4D as catalyst:

Area \% Report
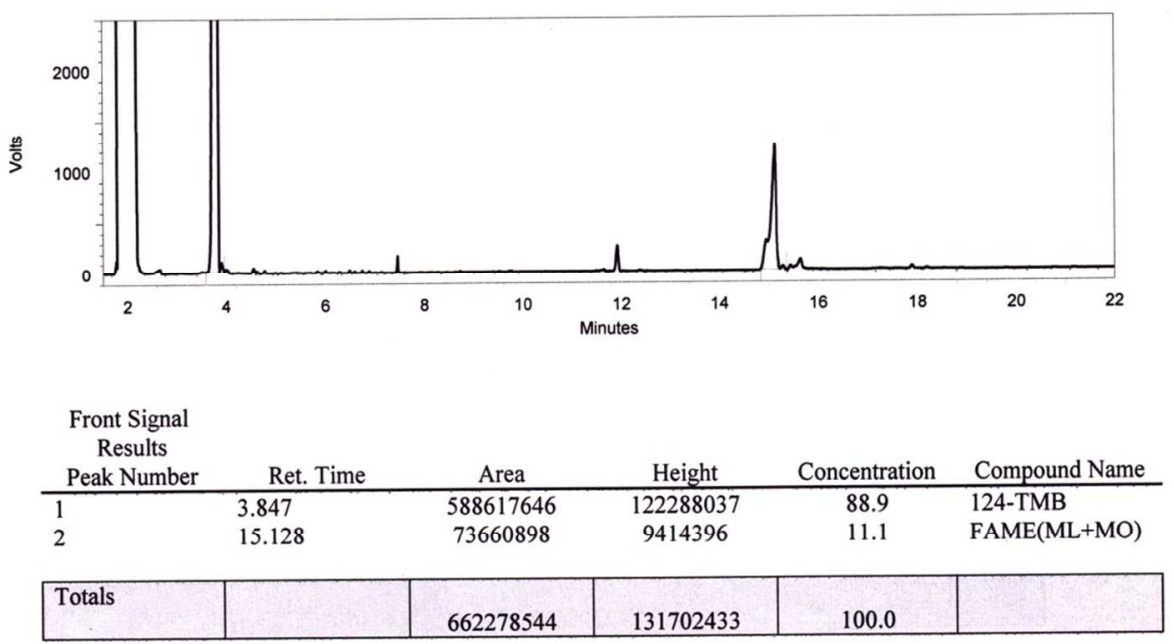

Conc: of FAME / conc: of 124-TMB $=0.124$

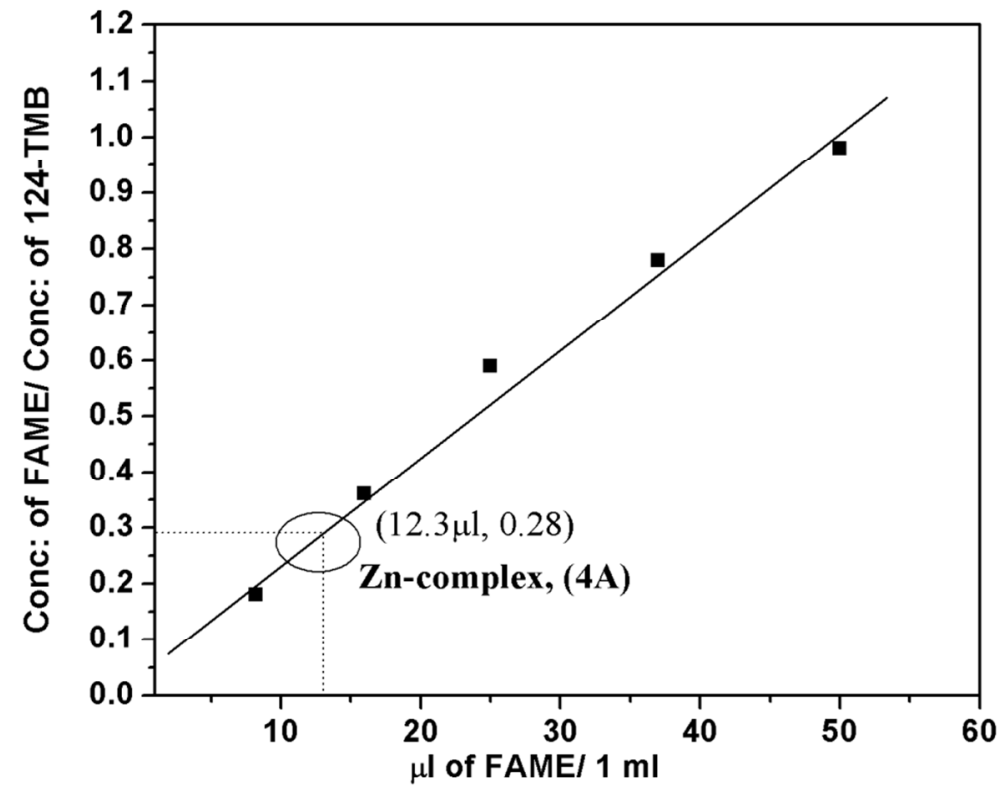

Figure S23. Calibration plot of FAME (MO+ML) to determine the amount of FAME formed in the catalytic reactions.

From the above calibration plot, the concentration of FAME (ML+MO) formed in the transesterification reaction of canola oil with methanol catalyzed by complexes $4 \mathrm{~A}, \mathbf{4 B}, \mathbf{4 C}$ and 4D were found to be $12.3 \mu \mathrm{l}, 1.36 \mu \mathrm{l}, 2.049 \mu \mathrm{l}$ and $4.62 \mu \mathrm{l}$ respectively. 